\title{
Required literacy and numeracy skill levels for occupations in OECD countries
}

Citation for published version (APA):

Pérez Rodriguez, S., Huijts, T., van der Velden, R., \& Jacobs, B. (2020). Required literacy and numeracy skill levels for occupations in OECD countries: Application of the Job Analysis Method to PIAAC. ROA. ROA Technical Reports No. 008 https://doi.org/10.26481/umarot.2020008

Document status and date:

Published: 02/12/2020

DOI:

10.26481/umarot.2020008

Document Version:

Publisher's PDF, also known as Version of record

\section{Please check the document version of this publication:}

- A submitted manuscript is the version of the article upon submission and before peer-review. There can be important differences between the submitted version and the official published version of record.

People interested in the research are advised to contact the author for the final version of the publication, or visit the DOI to the publisher's website.

- The final author version and the galley proof are versions of the publication after peer review.

- The final published version features the final layout of the paper including the volume, issue and page numbers.

Link to publication

\footnotetext{
General rights rights.

- You may freely distribute the URL identifying the publication in the public portal. please follow below link for the End User Agreement:

www.umlib.nl/taverne-license

Take down policy

If you believe that this document breaches copyright please contact us at:

repository@maastrichtuniversity.nl

providing details and we will investigate your claim.
}

Copyright and moral rights for the publications made accessible in the public portal are retained by the authors and/or other copyright owners and it is a condition of accessing publications that users recognise and abide by the legal requirements associated with these

- Users may download and print one copy of any publication from the public portal for the purpose of private study or research.

- You may not further distribute the material or use it for any profit-making activity or commercial gain

If the publication is distributed under the terms of Article $25 \mathrm{fa}$ of the Dutch Copyright Act, indicated by the "Taverne" license above, 


\section{Maastricht University ROA}

\section{Required literacy and numeracy skill levels for occupations in OECD countries}

\section{Application of the Job Analysis Method to PIAAC}

Sandra Pérez Rodríguez

Tim Huijts

Rolf van der Velden

Babs Jacobs

\section{ROA Technical Report}

ROA-TR-2020/8

Researchcentrum voor Onderwijs en Arbeidsmarkt | ROA Research Centre for Education and the Labour Market / ROA 


\section{Table of Contents}

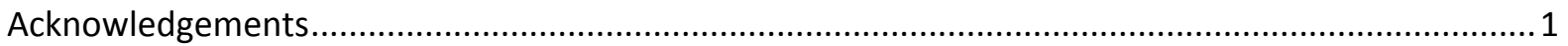

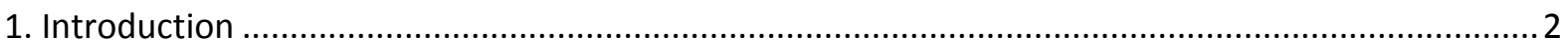

2. Occupations and skills: definitions, classifications, and frameworks .....................................

2.1 The International Standard Classification of Occupations (ISCO-08): classification of jobs into

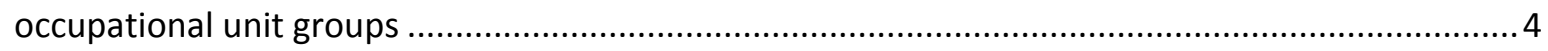

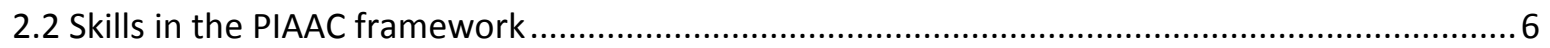

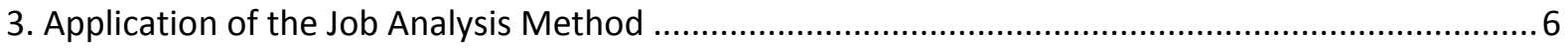

3.1 Description of the Job Analysis Method ................................................................... 7

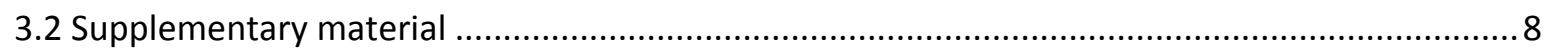

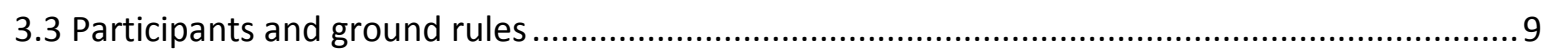

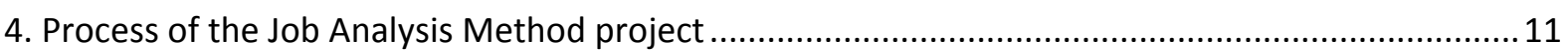

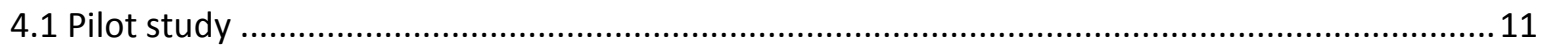

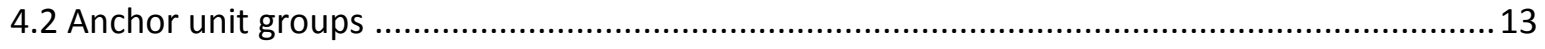

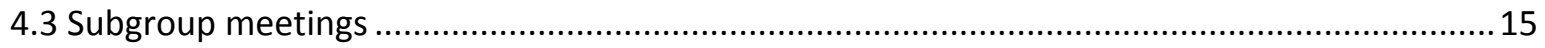

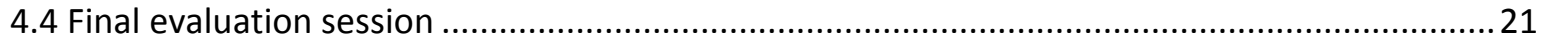

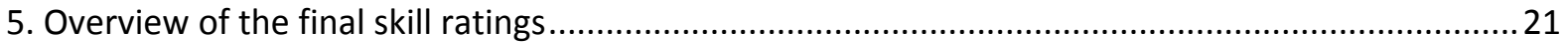

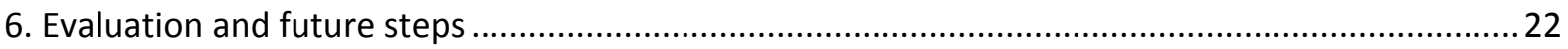

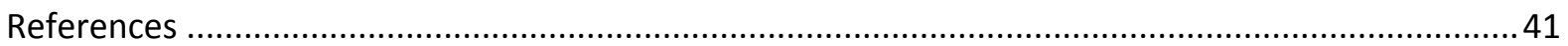

Appendix 1: ISCO-08 Major, Sub-major, Minor and Unit groups ............................................43

Appendix 2: PIAAC Proficiency levels: literacy and numeracy .....................................................58

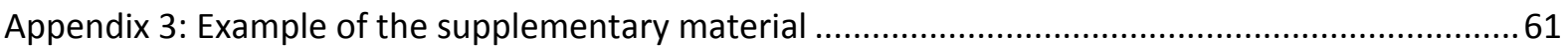

Appendix 4: Names and affiliations of the participating experts ........................................63 


\section{Acknowledgements}

This technical report is part of a research project conducted by the Research Centre for Education and the Labour Market (ROA). It is the result of a process of intensive collaboration with a group of experts: Margaret Birch, Peter Elias, Christy Gregory, David Hunter, Phil Lewis, Jean-François Rouet, Folker Schrödel, and David Tout. We are very grateful to them for their continued support for and dedication to the project. The results presented in this report are testimony to their extraordinary knowledge of occupational classifications and the skills required for a wide range of occupations. We also thank Marco Paccagnella, Glenda Quintini, and William Thorn from the OECD for their comments and suggestions on the project.

The research presented in this report was supported by a grant from NWO-NRO on behalf of the Dutch Ministries of Education, Culture and Science, Economic Affairs, and Social Affairs and Employment (grant 405-17-900/3504). We particularly thank Ted Reininga from the Ministry of Education, Culture and Science for his support for the project, and for his comments and suggestions.

Maastricht, September 2020

Sandra Pérez Rodríguez

Tim Huijts

Rolf van der Velden

Babs Jacobs 


\section{Introduction}

Skill mismatch is a situation of imbalance in which the level or type of skills available does not correspond to the skills required by the labour market (European Centre for the Development of Vocational Training, 2014; McGuinness, Pouliakas, \& Redmond, 2018). There is evidence that the degree of skill mismatch in OECD countries persists over time (OECD, 2016), and varies considerably across countries (Adalet McGowan \& Andrews, 2017). Skill mismatch represents a loss of investment for individuals, but also for society as a whole. It is therefore important to develop policies which help to promote the optimal utilisation of skills (Global Agenda Council on Employment, 2014). To achieve this, it is essential that policy makers can rely on reliable and accurate measures of skill mismatch.

Three different methods have been used so far to measure skill mismatch: worker self-assessment (the worker him/herself states the level required for his/her job), realized matches (taking the average skill level in an occupation as a proxy for the required level), and the job requirement approach (taking the frequency of use of a skill as a proxy for the required level of such skill). However, each of these methods comes with certain limitations. The first depends on the subjective evaluation of the workers, whereas the second and the third are based on the average level or use of a skill in an occupation, which may not necessarily match the actual skill requirements for this occupation (Van der Velden \& Bijlsma, 2019). Self-reported assessments are susceptible to bias, as workers are likely to overestimate their job's skill requirements (Perry, Wiederhold, \& Ackermann-Piek, 2014), while methods that consider average requirements or average skill use are controversial because they focus on the average characteristics of the workers, without considering the real requirements of the job (Desjardins \& Rubenson, 2011).

In its guidelines concerning measurement of qualifications and skills mismatches (International Conference of Labour Statisticians, 2018), the ILO further underlines this issue. Reflecting the concerns about the risk of bias in self-reported assessments of skill mismatch, these guidelines note (p.6) that "Wherever possible, in addition to the assessment by the person in employment, measurement might be based on the employer's assessment of skills possessed by the person in employment against the skills required to perform the job, and/or direct assessment of level of proficiency of selected types of skills (e.g. literacy, numeracy and ICT tests might be used)." The guidelines do not provide advice on how this should be done, but note the need for further methodological work.

One way of approaching this involves the assessment of skill requirements by occupational experts. Involving occupational experts is considered a reliable approach in the analysis of educational mismatch (Béduwé \& Giret, 2011; Dahlstedt, 2011; Katz-Gerro \& Yaish, 2003; Nordin, Persson, \& Rooth, 2010; Verhaest \& Omey, 2006; Wolbers, 2013), and could also be applied to the assessment of skill mismatch, as recommended by Van der Velden and Bijlsma (2019). The core idea here is that a normative approach in which occupational experts would establish the standard skill requirements per occupation would allow for an unbiased estimation of skill mismatch. Determining the objective requirements for occupations at an international level through this approach would help to further improve the accuracy of estimates of the incidence of skill mismatch in Western economies. This could in turn provide the ground for further research on the determinants of skill mismatch and policy recommendations.

The Job Analysis Method offers an approach that puts this core idea into practice. Applied to skill mismatch, this method requires professional occupational experts to assess the skill requirements per 
occupation, relying on occupational classification systems. Occupational classification systems are usually systematic and elaborate, clustering each job title under hierarchically nested categories, based partly on the required level and type of education and the required skills to perform the tasks that are involved in each job (Hartog, 2000). The classification system most commonly used internationally is the International Standard Classification of Occupations 2008 (ISCO-08) published by the International Labour Office (2012). Additionally, some countries provide their own standard classifications to better reflect the national labour market reality.

The data from the Programme for the International Assessment of Adult Competencies (PIAAC) from the Organisation for Economic Co-operation and Development (OECD) are the leading source for information on skill proficiency levels for individuals in modern economies. The PIAAC data are unique in combining a validated assessment-based measurement of skills with coverage of a large number of OECD countries. However, to estimate skill mismatch, one also needs to have information on the required skill level in the occupations in which these individuals work. That type of information is currently lacking in the PIAAC data. The aim of the project presented in this technical report was to apply the Job Analysis Method to the case of skill mismatch. Through the application of this method, occupational experts determined the critical skill level required for all occupational unit groups in the International Standard Classification of Occupations 2008 (ISCO-08) using the same framework that was applied to asses individuals' skill proficiency levels in PIAAC.

Therefore, in establishing the skill requirements through the Job Analysis Method, we use the PIAAC framework for defining and demarcating skill levels. PIAAC includes data on skill proficiency in three domains: literacy, numeracy, and problem solving in technology-rich environments. The latter is disregarded in this project due to a potential selection bias, as only individuals who have basic computer skills were tested in this domain. Therefore, our project focuses solely on literacy and numeracy skills. Although literacy and numeracy skills will not capture all of the many dimensions of skill mismatch, Levels, Van der Velden, and Allen (2014) provide evidence that skill mismatches in these domains explain a large part of educational mismatches. This is because literacy and numeracy are two critical key information-processing skills that are prerequisites for acquiring both job-specific technical skills and other general skills that are crucial for functioning well in the job.

Additionally, it is the use of the skill proficiency levels from PIAAC in determining skill requirements that makes this project of added value to existing research. While there is some information on required skill levels in occupations with respect to the domains of literacy and numeracy from other sources (e.g. the requirements regarding Reading Comprehension and Mathematics in the US Occupational Information Network O*NET), this information does not match with the definition of literacy and numeracy in PIAAC, nor does it provide those skill levels in the same metric as the PIAAC skill proficiency scales, which is essential to derive skill mismatch estimates.

Consequently, the central research question of this report is: What are the required literacy and numeracy skill levels in occupations in OECD countries? By answering this question, this project hopes to contribute to the further development of the international standards for measuring skill mismatch. In future steps of the project, the newly determined literacy and numeracy skill requirements per occupational unit group will be matched to the actual literacy and numeracy skill levels of the respondents in the PIAAC data, and can then be used to derive new estimates of the incidence of skill mismatch. 
This report is structured as follows: Section 2 describes the definition and operationalisation of the core concepts used in this project; Section 3 outlines the Job Analysis Method, and explains how we applied this to the case of skill mismatch; Section 4 describes the process we followed in linking the occupations to literacy and numeracy skill levels; Section 5 presents an overview of the newly determined skill requirements per occupational unit group; and we conclude in Section 6 with an evaluation of the application of the method and of the process we have followed.

\section{Occupations and skills: definitions, classifications, and frameworks}

\subsection{The International Standard Classification of Occupations (ISCO-08): classification of jobs into occupational unit groups}

Having reliable occupational information is important for several reasons. It improves the equilibrium in the labour market between supply and demand of jobs. Additionally, it can be used to provide youngsters and job seekers with adequate career counselling, as well as promote better policy-making in the field of the labour market (Office for National Statistics, 2010). Therefore, some national governments and supranational organizations have developed standard occupational classifications. They categorise jobs based on the requirements to perform the main duties of each job, with the purpose to promote statistical research in a consistent way. They are updated every few years to include changes in the labour market, such as the appearance and disappearance of jobs or the changes in job requirements as a result of new technologies.

The International Standard Classification of Occupations (ISCO-08) is considered to be the baseline occupational classification for international labour statistics among the international community. ISCO-08, developed by the International Labour Office (2012), categorises occupational information to provide an exhaustive framework for the compilation of internationally comparable data. It is the recognized international standard for occupational statistics. It was adopted in 2007 by a Meeting of Experts on Labour Statistics as mandated by a resolution of the Seventeenth International Conference of Labour Statisticians. It was endorsed by the Govening body of the ILO in 2008 and presented to the United Nations Statistical Commission. All in all, ISCO-08 serves several purposes: it allows for international comparison of occupational statistics, it is the baseline for the creation of national classifications, and it serves as the standard for occupational classifications in countries that do not have their own national classification.

More practically, ISCO-08 provides information relating jobs to skills. It defines a job as "a set of tasks and duties performed, or meant to be performed, by one person, including for an employer or in selfemployment". An occupation is defined as a "set of jobs whose main tasks and duties are characterized by a high degree of similarity". Similarly, ISCO-08 defines skills in terms of jobs as "the ability to carry out the tasks and duties of a given job" (International Labour Office, 2012, p. 11). This classification organizes its categories by considering two dimensions of the skills: skill level and skill specialization. Skill level refers to the complexity and range of the tasks and duties to be performed in an occupation, taking into consideration the nature of the work performed in relation to the characteristic tasks and duties defined for each ISCO-08 skill level, and the level of formal education and/or job-related training and/or previous experience required for competent performance. Skill 
specialization refers to the field of knowledge required for the occupation, the tools, machinery and materials used, and to the goods and services produced.

ISCO-08 is hierarchically structured in four different levels, from the broadest classification to the most detailed division, each level comprising a complete classification per se. As a consequence, ISCO-08 is composed of 10 (1-digit) major groups, 43 (2-digit) sub-major groups, 130 (3-digit) minor groups and 436 (4-digit) unit groups. Unit groups are clustered into minor groups, which are then arranged into sub-major groups, which are in turn clustered within the major groups. The 1-digit groups are organized primarily according to the skill levels required for the included occupations, whereas the more detailed decomposition is done according to skill specialization. In general terms, the aggregations are based on resemblance with regards to the tasks and duties performed, and the educational requirements for the included occupations. It is important to note that the 4-digit unit groups may consist of multiple occupations; unit groups are therefore not equivalent to occupations, but a device to cluster occupations with similar tasks and duties. Appendix 1 gives a full overview of all the levels of the ISCO-08 classification, including all the 436 4-digit unit groups.

Figure 1 relates the 10 major groups from ISCO-08 to their associated general skill levels. ISCO-08 clusters occupations in these groups based on 4 skill levels. Skill level 1 refers to occupations that involve the performance of simple and routine physical or manual tasks and may require completion of primary education. Skill level 2 comprises occupations that generally require completion of at least the first stage of secondary education, and typically involve manipulating information or operating, maintaining and repairing machinery. In some cases they require completion of vocational secondary education undertaken after completion of secondary education. Occupations at skill level 3 generally imply conducting practical tasks that require technical specialized knowledge usually acquired through tertiary education. Finally, occupations within skill level 4 are characterized by tasks that imply complex problem-solving and decision-making, requiring highly specialized knowledge that is typically acquired via higher education at the level of at least a first degree. As shown by Figure 1, the 10 major groups are organized to range from the ones that require the highest skill levels (groups 1 and 2) to the ones that require the lowest skill levels (group 9).

Figure 1 Mapping of ISCO-08 major groups to general skill levels

\begin{tabular}{lc} 
ISCO-08 major groups & Skill level \\
\hline 1 Managers & $3+4$ \\
2 Professionals & 4 \\
\hline 3 Technicians and Associate Professionals & 3 \\
4 Clerical Support Workers & 2 \\
5 Services and Sales Workers & \\
6 Skilled Agricultural, Forestry and Fishery Workers & \\
7 Craft and Related Trade Workers & 1 \\
\hline 8 Plant and Machine Operators, and Assemblers & $1+2+4$ \\
9 Elementary Occupations & \\
0 Armed Forces Occupations & \\
Figure 1. Mapping of ISCO-08 major groups to skill levels. Reprinted from "International Standard Classification of \\
Occupations: ISCO-08. Structure, group definitions and correspondence tables", by the International Labour Office, 2012, Vol \\
1, p. 14. Copyright 2012 by the International Labour Organization.
\end{tabular}


There are some occupations in which the educational and skill requirements are different across countries. ISCO-08 addresses this issue by prioritizing the tasks performed over the formal requirements when classifying an occupation. Therefore, occupations that imply the realization of similar tasks and duties will be located under the same category, even if the educational and skill requirements to access them diverge between countries. This arrangement facilitates international comparability, which is one of the main purposes of ISCO-08.

\subsection{Skills in the PIAAC framework}

The PIAAC project, carried out in 38 countries, collects data from country-specific household samples of individuals ranging from 16 to 65 years old. PIAAC includes direct measures of adults' proficiency in several key competencies as it contains a direct assessment of skills, as well as a wide variety of questions regarding skill use. Furthermore, PIAAC includes a background questionnaire comprising demographic, educational, and labour status information (OECD, 2013). PIAAC focuses on three skill domains: literacy, numeracy and problem-solving in technology-rich environments. As mentioned in Section 1, we did not consider the latter in this project due to a potential selection bias, and focus solely on literacy and numeracy skills.

According to the $\operatorname{OECD}(2013$, p. 20$)$, literacy is defined as "the ability to understand, evaluate, use and engage with written texts to participate in society, to achieve one's goals, and to develop one's knowledge and potential. It encompasses a range of skills from the decoding of written words and sentences to the comprehension, interpretation, and evaluation of complex texts". It should be noted here that writing skills are not covered in the literacy framework of PIAAC. The reasons for this are partly practical: it is difficult to assess writing skills through test-based assessments, especially if the aim is to achieve comparable skill proficiency scores across countries. In assessing literacy skill requirements through the Job Analysis Method, it is therefore important that writing skills are not taken into account, since this would hamper the correspondence between the data on skill requirements and the data on literacy skill proficiency from PIAAC. However, we can safely assume that literacy skills as defined in the PIAAC framework are strongly correlated with writing skills, and that most occupations that require a high level of literacy would also require a high level of writing skills.

The $\operatorname{OECD}(2013$, p. 20$)$ defines numeracy as "the ability to access, use, interpret and communicate mathematical information and ideas in order to engage in and manage the mathematical demands of a range of situations in adult life". A separate assessment for each of these skills was carried out, and resulted in scores on a continuous scale between 0 and 500 . These scores were then clustered into six proficiency levels, ranging from 1 to 5 plus a 'below 1' category (which indicates that respondents lack the basic literacy or numeracy skills required for proficiency level 1), with 'below 1 ' being the lowest proficiency level and 5 the highest. Appendix 2 provides an explanation for each of the proficiency levels, based on the PIAAC literacy and numeracy frameworks, as well as an equivalence table between the proficiency levels and the score points.

\section{Application of the Job Analysis Method}

We have applied the Job Analysis Method to the field of skill mismatch, by employing occupational experts to rate the literacy and numeracy requirements of the 4-digit occupational unit groups coded 
under the International Standard Classification of Occupations (ISCO-08), using the literacy and numeracy skill frameworks of PIAAC. In this section, after a brief description of the core elements of the Job Analysis Method, we explain how we have applied this method to recruit the occupational experts who conducted the rating process, and to prepare the materials that we provided to the experts to inform their ratings.

\subsection{Description of the Job Analysis Method}

Job Analysis is the method that decomposes jobs into different factors, such as tasks, by applying a standardised process to gather, analyse, and report data about these factors. This standardised process is used for the identification of a job's characteristics, as it provides information about tasks, hierarchy among staff within a job, and the knowledge, skills, and abilities necessary to perform such a job (American Educational Research Association, American Psychological Association, \& National Council on Measurement in Education, 2014). The Job Analysis Method has been used for setting the selection requirements for potential job applicants. Moreover, it is widely utilised within the Human Resources field to evaluate how workers perform at the workplace, organise compensation plans and conceive training programs (Surrette, Aamodt, \& Johnson, 1990). In addition, designating the requirements to perform a job usually culminates in having a more complete job description, permitting an adequate job classification, a re-adjustment of the job if necessary, and the preparation of a recruitment plan (Brannick \& Levine, 2002). Moreover, the occupational information gathered through the Job Analysis Method contributes to the matching process done by employment agencies, offers career guidelines to students and recent graduates, and facilitates labour market related policy making (Office for National Statistics, 2010).

The first step of the Job Analysis Method implies collecting as much background information as possible about the job. This includes staffing structure, studying how the job relates to similar roles, specific tasks, and expectations (Jenkins \& Curtin, 2006). According to Hartog (2000), the purpose of the Job Analysis Method is objectivity, as trained occupational analysts evaluate the job focusing on its technology and the type of activities to be done. Nonetheless, this method relies on the existence of detailed and updated data, as highly aggregated classifications are prone to bias and can quickly become outdated (Dahlstedt, 2011). Hence, the Job Analysis Method is considered an objective method if very specific and observable descriptor items are utilised, and if the type of judgement the rater has to make is concrete, constant across jobs, and verifiable. Raters who were able to use detailed information consistently provide more accurate analyses than those who only received information about the job title. Similarly, Dierdorff and Wilson (2003) show that providing a detailed explanation of concrete tasks used in the job generates a higher interrater and intrarater reliability than when only generic work activities are described. Also, training the analysts adequately improves their judgement, thus leading to higher reliability. Raters who did not get training experienced difficulties in distinguishing between relevant and irrelevant skills and competences (Lievens \& Sanchez, 2007).

When determining skill requirements of occupational unit groups rather than jobs, another factor that may influence accuracy is heterogeneity between jobs within a occupational unit group. Accuracy is higher when there is little within-unit group heterogeneity, since this heterogeneity can cause aggregation bias, making the outcome of the Job Analysis Method a poor quality descriptor of the true 
job requirements (Harvey \& Wilson, 2000). In fact, $25 \%$ of the variance between raters when rating jobs within the same occupational group is due to heterogeneity in the complexity, the context, and the nature of the tasks of the jobs within the occupational group (Lievens, Sanchez, Bartram, \& Brown, 2010).

All in all, to apply the Job Analysis Method to the case of skill mismatch, we needed to select a multidisciplinary group of experienced occupational experts, offer them an adequate training, and provide them with concrete information about occupational unit groups that includes details on specific job titles and the relevance and frequency of tasks and skills. In addition, potential within-unit group heterogeneity in tasks and skills should be taken into consideration. If this procedure is followed, the Job Analysis Method is an objective, accurate and reliable measure of the skill requirements across occupational unit groups.

\subsection{Supplementary material}

We prepared supplementary material for each unit group in order to provide the experts with the relevant information required for the Job Analysis Method. The ISCO-08 4-digit classification is composed of 436 unit groups. However, Major group 0 "Armed Forces Occupations" has been excluded from the analysis, given their intrinsic heterogeneity. Therefore, a total of 433 unit groups have been considered in this project.

The supplementary material comprises a description of each unit group, including a list of tasks and examples of job titles classified in each unit group from the International Standard Classification of Occupations 2008 (ISCO-08) from the International Labour Office (2012). Moreover, we matched the ISCO-08 unit groups with the American Standard Occupational Classification 2018 (2018 SOC), using the official crosswalk, in order to obtain the required education and experience to do the job from O*NET (2019). Moreover, we have included the frequency of the use of literacy and numeracy skills at the workplace, derived from the PIAAC data (OECD, 2018). An example of the supplementary material for one unit group is displayed in Appendix 3. The complete supplementary material is available online.

Each unit group had its own information sheet, starting with a detailed description of what the unit group entailed, as well as the most important tasks that are conducted, based on international standards (ISCO-08 classification). This description was followed by information on the educational degree and professional experience that is usually required to access the job in the United States, as this information originates from the O*NET database of 2019 (SOC 2018). The matching between the ISCO-08 and 2018 SOC is not perfect, as the American classification contains approximately twice as many groups as the international classification and the two classification systems are not based on the same conceptual models. Therefore, we have used the official crosswalk, double-checking for potential issues. If an ISCO-08 unit group was matched to multiple 2018 SOC occupations, we chose the most plausible pairing, based on the description of the tasks. Moreover, for a limited number of occupations in ISCO-08, there was no matching occupation in 2018 SOC. In the information sheets for such unit groups, we explained that there was no information available regarding the required education and experience.

Data regarding the frequency of the use of literacy and numeracy skills at work for each unit group were derived from the PIAAC data (OECD, 2018). In the PIAAC survey, respondents were asked how 
often they used various literacy and numeracy skills in their current job (or in their last job, if they were not working at the time of the survey). Originally this information was included in the unit group information sheet, but it soon became clear that the skill use frequencies could be misleading, and should hence be used only as additional material, instead of as the main source of information to rate the skill requirements of the unit groups. Therefore, the frequencies of literacy and numeracy skill use at work for each unit group were provided to the experts in a separate excel file. For representativity purposes, information on skill use was only included for unit groups with at least 25 respondents. This excel file is also available online.

Finally, the experts received information regarding the conceptualisation and measurement of literacy and numeracy skills in the PIAAC framework, including a description of each level (as shown in Appendix 2). Moreover, they were given short presentations explaining what each skill entails, and specific examples of tasks that people at each skill level should be able to perform. Furthermore, the occupational experts received a training from the chairs of the PIAAC literacy and numeracy subject matter expert groups, who were also available for clarification and questions throughout the process.

\subsection{Participants and ground rules}

The core principle of the Job Analysis Method is that occupational experts rate unit groups based on the supplementary material they have been provided with, as well as their own expertise. Therefore, we have selected two domain experts (one for literacy, one for numeracy) and six professional occupational experts for this project. The domain experts are the chairs of the PIAAC literacy and numeracy subject matter expert groups. Regarding the occupational experts, they have different professional backgrounds (O*NET, Job Networking Solutions, StatClass, Warwick University, and BW Verlag), and bring together expertise on ISCO, O*NET, and the German and British national classifications. Moreover, to ensure geographical representation, the experts are based in different countries: Australia, France, Germany, Switzerland, United Kingdom and United States. Several of the experts have extensive international experience and are familiar with multiple national classification systems. A full list of participants and their affilliations can be found in Appendix 4.

Consequently, we have provided the experts with the supplementary material that was previously described, and asked each of them to make an initial judgement of what level of literacy and numeracy skills people would typically need for the occupations in each unit group. These initial ratings served as a starting point to facilitate the discussion and gave us an early indication of the level of agreement and disagreement among the experts. The organization of the rating process was based on the Occupational Information Network (O*NET) Skill Ratings Procedure described by Fleisher and Tsacoumis (2018).

Finally, the experts were asked to rate unit groups according a number of ground rules, which were not included yet with the supplementary material. These ground rules address a number of issues relating mostly to the literacy and numeracy frameworks from PIAAC, and to the issue of within-unit group heterogeneity that was described in Section 3.1. The exact ground rules that the experts were given were phrased as follows:

1) Think of 'iteracy' and 'numeracy' as key information-processing skills, as described in the literacy and numeracy skill levels from the PIAAC framework. The important thing to note is that literacy and 
numeracy are not simply basic skills, but represent key information-processing skills that can be applied to simple but also very complex tasks. Additionally, please do not consider writing skills in your ratings for literacy. After all, the focus of the PIAAC study is on information-processing literacy and numeracy skills, and writing skills were not directly assessed.

2) The ratings should be focused on critical skills, that is, the minimum skills required to do the job, instead of optimal skills.

3) It is still possible that there is within-occupation heterogeneity in the tasks that people in a unit group are required to perform. This is particularly the case if multiple examples of occupations are classified in a unit group (as shown in the 'Definition and tasks' section of the description of the unit group). Please take this into account in the ratings as follows:

a) When the examples of occupations are clear, and one occupation dominates over the other occupations, the rating will be based on the dominant occupation within the unit group.

b) When the examples of occupations are not clear, e.g. when an occupation is included in an occupational unit group because it does not fit anywhere else, experts are asked to rate based on the ISCO-08 tasks definition.

c) When there is clear heterogeneity and thus the unit group cannot be rated with only one level, there is the possibility to use combined ratings, for instance, level $1+2$. We have introduced the option of combined ratings to identify and rate heterogeneous categories that would otherwise be difficult to rate given their nature.

4) Even after taking within-occupation heterogeneity into account, it is possible that for some occupations it is difficult to decide on the exact skill level needed (e.g., should the literacy skill level be rated 2, or rather 3?). To deal with uncertainty for such cases, we have also provided the opportunity to use between-level ratings (e.g., literacy skills 'level 2.5'), or multiple-level ratings (e.g., literacy skills 'level $2+3$ '). Therefore, we have turned the PIAAC scale from 6 levels (below level 1 to level 5) to a scale of 11 , plus 5 combined ratings for heterogeneous unit groups, hence 16 levels in total. Moreover, for clarity reasons, we have renamed PIAAC's 'below level 1' category as 'level 0 '. Thus the scale to be used is: Level 0, Level 0.5, Level $0+1$, Level 1, Level 1.5, Level 1 + 2, Level 2, Level 2.5, Level $2+3$, Level 3, Level 3.5, Level $3+4$, Level 4, Level 4.5, Level $4+5$ and Level $5 .{ }^{1}$

5) When rating the occupations, please think of the skills that are required for each occupation now, in 2020. We recognize that ISCO-08 is over 10 years old, and that the next classification will not be published until 2025 or later. Moreover, technology has developed a lot throughout the years, and technology has changed and will continue to change tasks and occupations. However, it will be difficult to take into account (or to predict) when and how tasks for each occupation will change exactly. We understand that this means that the skill ratings may need to be revised and updated after 5 or 10 years.

1 This more elaborate scale was used in the main phase of the process. In the pilot study, we still used the original PIAAC scale. 


\section{Process of the Job Analysis Method project}

The Job Analysis Method project took place in several phases, as summarized in Figure 2. As a starting point, we conducted a pilot study with some of the experts to test the functioning of the method, as well as to give the experts the opportunity to practice and give feedback regarding the methodological design. After the success of the pilot study, we officially started the project by hosting a joint meeting, where we provided the experts with training about the conceptualization of literacy and numeracy skills, and then jointly rated a group of anchor occupation units that would later on be the basis for the remainder of the project. Afterwards, the project was structured in rounds, giving the experts the option to revise and change previous ratings if necessary, in order to account for an increased accuracy over time based on experience. This section describes the process of the project, highlighting the most important points of discussion from each meeting. All meetings were supervised by researchers from ROA, who also provided all the supplementary material and prepared minutes of the meetings.

\subsection{Pilot study}

The pilot study tested the functioning of the method, by focusing on a limited number of occupations. We selected 16 unit groups from ISCO-08, choosing unit groups with some of the most representative and prevalent occupations. First, we made a list of the unit groups with most observations per submajor group to ensure that the selected groups would be large enough to guarantee the viability of the analysis. Then we chose 16 unit groups with the aim of representing the whole spectrum of literacy and numeracy skills and all ISCO-08 major groups. This choice was based on the average PIAAC literacy and numeracy skill proficiency levels per unit group in the Netherlands. Nonetheless, due to time limitations, only 10 unit groups were assessed during the meeting.

We organised an online meeting with three occupational experts (one from the Warwick Institute for Employment Research, one from Job Networking Solutions, and one from StatClass), as well as the chairs of the PIAAC literacy and numeracy expert groups to jointly rate these unit groups. The purpose of this online meeting was to establish the critical literacy and numeracy skill requirements on the PIAAC scale (that is, from levels 1 to 5 ) for each ISCO-08 unit group. 
Figure 2 Summary of the process of the Job Analysis Method project

\section{Pilot Study (14 ${ }^{\text {th }}$ of June 2019)}

3 occupational experts +2 domain experts

10 example unit groups

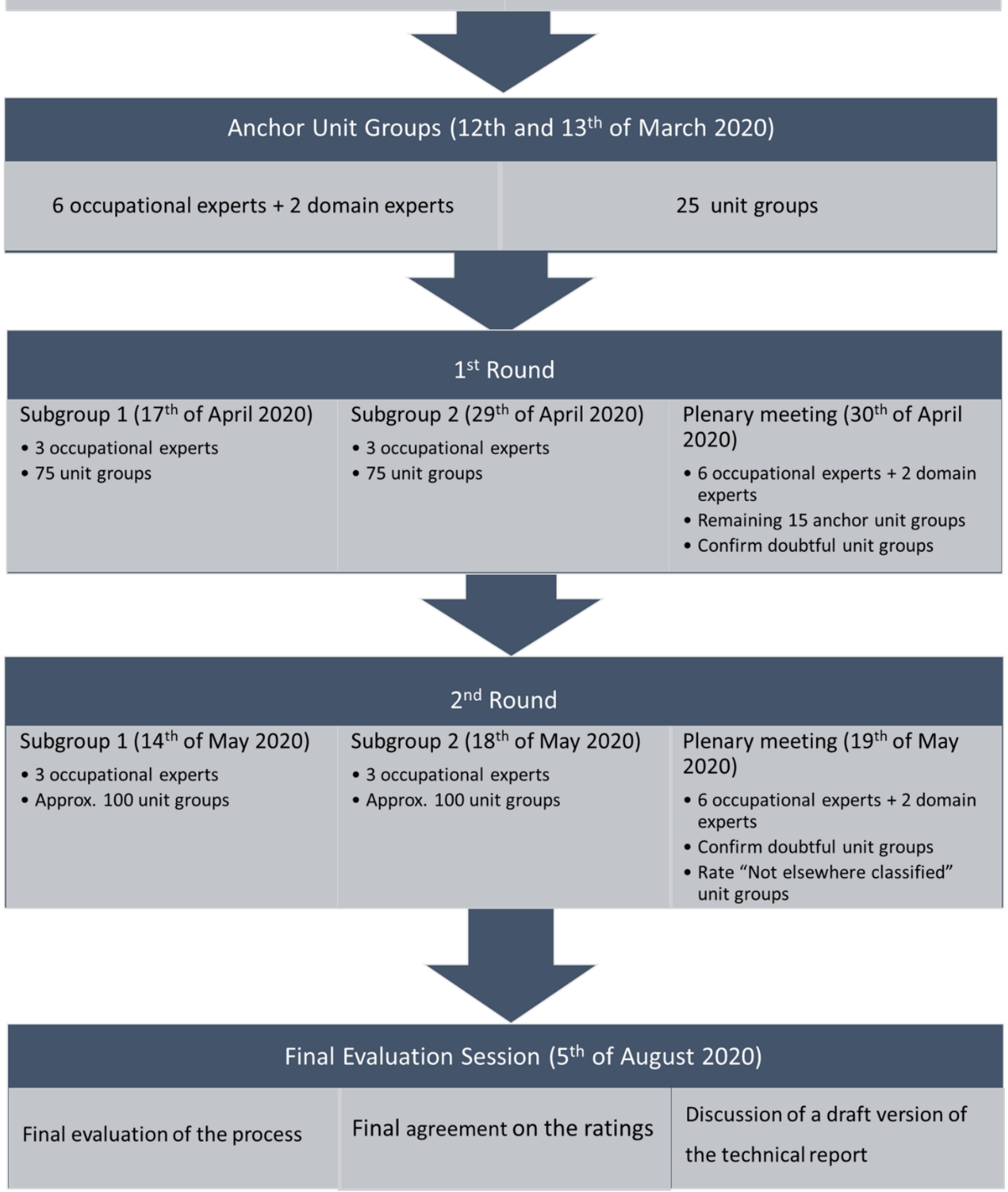


Prior to the meeting, the experts received supplementary material ${ }^{2}$ (as described in Section 3.2 ) to assist them in their task to determine the critical skill requirements. The experts received the material one week before the meeting took place and were asked to individually do a preliminary rating of the unit groups. The results were merged to check in which unit groups there was most consensus, in order to determine the order of the discussion during the meeting. The online meeting, which took place on the $14^{\text {th }}$ of June 2019, began with an initial explanation of the literacy and numeracy concepts in the PIAAC framework. Afterwards, the experts discussed the literacy and numeracy skill requirements, unit group by unit group. For each unit group, one of the experts was asked to explain his or her preliminary ratings and then the other experts were asked to express their views until an agreement was reached. At the end of the meeting, an evaluation session took place, discussing the success of the method, improvements to be made, and future steps of the project. All in all, the experts agreed that it was important to continue developing the Job Analysis Method for estimating skill mismatch, and to also apply the method to the remaining unit groups at the 4-digit level. A complete summary and evaluation of the pilot study is available upon request from the authors.

\subsection{Anchor unit groups}

\section{Participants}

The first workshop of the Job Analysis Method project took place on the $12^{\text {th }}$ and $13^{\text {th }}$ of March 2020. The participants in this two-day meeting were the chairs of the PIAAC literacy and numeracy expert groups and six occupational experts from the Warwick Institute for Employment Research (Warwick University), O*NET, Job Networking Solutions, StatClass, and BW Verlag. Originally, the workshop was planned to be organised at the OECD headquarters in Paris, but the travel restictions due to the Covid19 pandemic made it impossible to have a physical meeting. Therefore, the physical meeting was replaced by an online workshop, spread over two days, in two four-hour sessions.

\section{Unit groups discussed}

ISCO-08 is composed of 436 unit groups, which are clustered into 40 sub-major groups. Therefore, we selected the most predominant unit group out of each sub-major group as an anchor unit group, using information on the number of workers in each unit group from the PIAAC data. In some cases, the most predominant unit group was the "Not Elsewhere Classified" unit group, that comprises all related job titles that cannot be classified under any of the other unit groups. In those cases, ROA researchers selected the most representative unit group as the anchor, based on the tasks description. The anchor unit groups were used as a starting point to rate all related unit groups, whose skill requirements would then be considered in relation to the corresponding anchor unit groups. Therefore, the anchor unit groups were the starting point of the project.

After an extensive discussion of the ratings (in a similar way as during the pilot study), we aimed to arrive at a unanimous rating for the anchor unit groups. Nonetheless, we ensured that in case of doubt, the experts would still have the opportunity to revisit the ratings for these unit groups at a later stage in the process. Originally, the 40 anchor unit groups were planned to be discussed during the

2 For the pilot study, the materials also included information on median skill use; this proved to be confusing rather than helpful in the rating process, and we decided to not provide this information in the materials for the next steps of the project. 
sessions of the $12^{\text {th }}$ and $13^{\text {th }}$ of March 2020, but given the unforeseen constraints due to Covid-19, only 25 unit groups were rated within the available time. The remaining anchor unit groups were discussed during a plenary meeting that took place on the $30^{\text {th }}$ of April 2020. The following subsection summarizes the key discussion points of the meeting. A detailed description of the discussions on specific ratings is available upon request from the authors.

\section{Main points of discussion}

First, the two-day meeting started with a brief recap of the ground rules, as already presented in Section 3. Afterwards, the literacy and numeracy experts gave a short explanation of the PIAAC framework on literacy and numeracy skills, as a follow-up on the presentations they had distributed in advance among the occupational experts. These presentations included concrete examples of potential tasks corresponding to each of the PIAAC literacy and numeracy skill levels, as a way to further inform the occupational experts about the definition, interpretation, and application of the concepts of literacy and numeracy skills.

The meeting continued with the selection of three occupational unit groups as typical representatives of unit groups with "high", "intermediate" and "low" literacy and numeracy skills, in order to establish a framework to compare the remaining anchor unit groups. Starting with literacy, unit group 1112 Senior Government Officials was chosen as the highest level, unit group 3123 Construction Supervisors was considered to be of an intermediate level, and unit group 9510 Street and Related Services Workers was selected as a representative of the lowest level. Regarding numeracy, the unit group with the highest level was 2145 Chemical Engineers, whereas 2341 Primary School Teachers was chosen as the intermediate level representative. Finally, as with literacy, unit group 9510 Street and Related Services Workers was also considered as the lowest level for numeracy.

Then, the remaining anchor unit groups were discussed, following the order of the ISCO-08 unit group codes. As previously explained, the experts were asked to rate the unit groups individually and send them to ROA researchers in advance, who combined them and prepared preliminary ratings, which were then used as the starting point of the discussion. There was a certain level of heterogeneity among the individual ratings, mostly due to differences in understanding of the PIAAC proficiency levels, as well as personal upward or downward biases. By allowing an open discussion, during which one expert started by explaining his or her individual rating and the other experts responded freely, misunderstandings were addressed. Experts were asked to reach uninanimous consensus and were given the opportunity to flag unit groups to be discussed at a later stage if they did not feel fully confident about the ratings.

In total, 25 unit groups were rated during this two-day meeting. Full agreement was swiftly reached in the majority of cases after clarifying potential doubts regarding the tasks performed and the corresponding proficiency level. Only two unit groups (2221 Nursing Professionals and 2341 Primary School Teachers) were flagged to be revisited at a later stage. Regarding the former, there were disagreements about the tasks performed by nursing professionals, as there are different degrees of medical autonomy in the different countries. Regarding the latter, some experts asked to review the rating for primary school teachers once related occupations, such as high school teachers, had been rated, in order to keep intra-group consistency. Therefore, both unit groups were discussed and confirmed during subsequent meetings. 


\section{Evaluation}

We finalised the workshop with a review of the process and a fruitful discussion about the methodology. The following points were discussed and agreed:

1) Given that there is heterogeneity, it would be helpful to know which is the dominant job title within the unit group. However, this information is not available at the international level. Experts are therefore asked to rely on their own knowledge, as well as national occupational resources such as CASCOT or the classification of European Skills/Competences, Qualifications and Occupations (ESCO).

2) Similarly, if the experts feel that the ISCO-08 description is outdated for some unit groups, they should rely on these additional sources as well as on their own expertise.

3) The experts should rate occupations based on the average worker, not an entry level or senior worker.

4) The information provided on the frequency of skill use can be misleading. Therefore, for the next steps in the process, this information was separated from the main source material, and it was agreed that this should only be used as additional information.

5) The experts should try to stick to the PIAAC skill levels as much as possible. However, if they cannot reach consensus, they can provide an intermediate level rating (e.g. 1.5). If there is substantial variation in required skills within a unit group, the experts should give a combined level rating (e.g. levels $1+2$ ).

6) Once all unit groups have been rated, we should consider how each unit group is rated relative to other unit groups.

\subsection{Subgroup meetings}

After rating more than half of the anchor unit groups, we organised two rounds of online meetings. Each round was divided into two subgroup meetings and a plenary meeting. Each subgroup was composed of three occupational experts, whereas all the occupational experts and the literacy and numeracy experts took part in the plenary meeting. The composition of the subgroups was changed between Round 1 and Round 2, to further enhance interrater reliability.

The whole group was divided into subgroups to facilitate the discussion of the unit groups, given that in most cases there was already an anchor unit group to use as a reference point. Nonetheless, if for any of the ratings in the subgroup meetings no clear agreement was reached, the unit group concerned was referred to the plenary meeting to be discussed with the wider group. In addition, after each round, the ratings were sent to the whole group of experts to either confirm the ratings or to propose any changes for further discussion.

\subsubsection{Round 1 -Subgroup 1}

\section{Participants}

The three occupational experts who participated in this online meeting were from the Warwick Institute for Employment Research (Warwick University), Job Networking Solutions, and O*NET. The experts were required to provide their individual ratings prior to the meeting, which were combined 
by ROA researchers to provide a starting point for the discussion. The meeting was held online on the $17^{\text {th }}$ of April 2020.

\section{Unit groups discussed}

The experts were asked to rate 75 unit groups that were related to the anchors discussed in the previous meeting. The unit groups were clustered by sector. The clusters were designated by ROA researchers based on similarities between unit groups. The logic behind this was that unit groups within the same cluster may be similar, and could hence be rated relative to each other. These clusters were purely used for orientation and only provided as an additional tool, and experts were free to use them as they saw fit. The sectors assigned to this subgroup were: managers, finance, administration, government, sales \& services, and cleaning.

\section{Main points of discussion}

The ratings were discussed by groups of related unit groups, first for literacy and then for numeracy. The experts unanimously agreed on approximately a third of the unit groups, and when there was disagreement, it was usually minor. More concretely, for literacy (numeracy) there was a perfect match in 29 (27) unit groups and an almost perfect match (only half a level difference for one expert) in 14 (16) unit groups. The difference was one level for 27 (28) unit groups. There was only full disagreement (differences in skill ratings of more than one skill level between experts) for 5 unit groups in terms of literacy and 4 in terms of numeracy. In the cases where the experts unanimously agreed prior to the meeting, the rating was automatically established and the unit group was not explicitly discussed.

Overall, agreement was reached quickly during the meeting, and there were only a handful of problematic unit groups. There was a lack of understanding of the real meaning of unit group 1113 (Traditional Chiefs and Heads of Villages) as it is almost non-existent in the OECD countries (which is the main area of focus for this study), thus postponing its rating to the plenary meeting with all the experts. There were other cases where the ISCO-08 description was outdated, hence not fully representing the current reality of the unit group. Nonetheless, the experts decided to still consider the ISCO-08 description as the base for the rating, as it is the international standard source of information regarding occupations. In the end, four occupations were highlighted to be reviewed at the plenary meeting: 1113 Traditional Chiefs and Heads of Villages, 5111 Travel Attendants and Travel Stewards, 5113 Travel guides and 9520 Street Vendors (excluding Food). A full description of the discussions on specific ratings during this meeting is available upon request from the authors.

\subsubsection{Round 1 - Subgroup 2}

\section{Participants}

Three occupational experts took part in the Round 1 - Subgroup 2 meeting, which took place online on the $29^{\text {th }}$ of April 2020. The background of the experts is the Warwick Institute for Employment Research, StatClass, and BW Verlag. Following the standard procedure, the experts submitted their individual ratings prior to the meeting, which were combined by ROA researchers to obtain preliminary ratings. 


\section{Unit groups discussed}

75 unit groups were rated during this meeting, which mostly belonged to the same sub-major groups as the anchors that had already been discussed in previous meetings. They were organised in clusters of sectorally related unit groups to facilitate the ratings and promote intra-group consistency. The sectors assigned to this group were: mathematics, industry, agriculture, information, driving, and a mixed group containing those unit groups that could not be classified in any other cluster.

\section{Main points of discussion}

There was a perfect match for 38 unit groups for numeracy and 43 unit groups for literacy. The match was almost perfect (only half a level difference for one expert) for 23 unit groups for numeracy and 10 unit groups for literacy. There was a difference of maximum one level for 11 unit groups for numeracy and 18 unit groups for literacy. There was more than one level difference for only 3 unit groups for numeracy and 4 for literacy. This underlined the great consensus among the raters, even before the meeting. As a consequence, only the unit groups for which there was some disagreement were explicitly discussed during the meeting. Overall, the rating process was smooth and no unit group was particularly difficult to rate. The only concern was that for a limited number of unit groups the tasks described in ISCO-08 no longer fully represent the reality of occupations included the unit group. However, this issue was overcome thanks to the analysts' expertise and the possibility to use additional sources of information, such as the European Skills/Competences, Qualifications and Occupations classification (ESCO), O*NET, and other national classifications. The detailed description of the discussions on specific ratings from this meeting is available upon request from the authors.

\subsubsection{Round 1 - Plenary meeting}

\section{Participants}

The plenary meeting was attended by all of the occupational experts and the literacy and numeracy experts. It was held online on the $30^{\text {th }}$ of April 2020.

\section{Unit groups discussed}

The occupational experts had difficulties assigning the correct required skill level for a couple of cases during the subgroup meetings. For these unit groups, input was requested from the whole group, and especially from the literacy and numeracy experts. Therefore, the main purpose of the plenary meeting was to review difficult unit groups, as well as to rate the remaining anchor unit groups. In addition, two unit groups were added to the anchor groups for which already agreement had been reached in the pilot. These unit groups were: 2120 Mathematicians, Actuaries and Statisticians and 2212 Specialist Medical Practitioners.

\section{Main points of discussion}

The meeting started by reviewing the four unit groups that were problematic during the subgroup meetings.

Starting with 1113 Traditional Chiefs and Heads of Villages, the experts decided to base the rating on requirements in those OECD countries where occupations in this group exist, possibly assigning a relatively higher level to this unit groups than if all developing countries were taken into account. The reason is that PIAAC is primarily conducted in OECD countries and the ultimate goal of this project is 
to estimate skill mismatch in the PIAAC framework. Moreover, it was noted that in many countries (including several OECD countries) traditional chiefs and heads of villages increasingly need to be able to interpret both text and numerical information from both government agencies and private sector agencies in order to effectively inform and represent the interests of their communities.

Regarding 5113 Travel Guides, there was clarification of the heterogeneity in this unit group, thus motivating the experts to choose a combined rating as the solution. Once this unit group was discussed, the experts could rate 5111 Travel Attendants and Travel Stewards in comparison. Finally, the uncertainty regarding unit group 9520 Street Vendors (excluding food) was resolved by considering the frequency of returning the correct amount of change (a potential low level 2 task). Given that street vendors usually sell a limited amount of products at a fixed price, their numeracy requirements are lower.

After rating the problematic unit groups, the experts continued by discussing the remaining anchor unit groups. Overall, the rating process went smoothly, given the acquired experience with the process. Finally, the experts reviewed 2221 Nursing Professionals that had been flagged during the meetings of the $12^{\text {th }}$ and $13^{\text {th }}$ March 2020, and decided to increase the numeracy rating, given the better understanding of the concrete tasks that are performed in this unit group. A detailed description of the discussions on specific ratings during this meeting is available upon request from the authors.

\section{Evaluation of Round 1}

The experts were very positive about the evolution of the process. Even though they noted a difference between the official descriptions of levels and tasks in ISCO-08 and how in practice these were applied in national coding processes, they were able to agree on appropriate ratings by combining national information with the ISCO-08 information. The main concern was that, in some cases, the ISCO-08 description was not up to date, mainly due to automatisation and other technological changes that have taken place in recent years. Nonetheless, by combining the ISCO-08 descriptions with the knowledge of the experts and additional sources of information, the rating process was considered reliable and the ratings representative of the current skill requirements.

\subsubsection{Round 2 - Subgroup 1}

\section{Participants}

Following the same structure as Round 1, Round 2 was organised in two subgroup meetings and a final meeting. The meeting of the first subgroup took place on the $14^{\text {th }}$ May 2020 and was held online. The participants were three occupational analysts from the Warwick Institute for Employment Research, Job Networking Solutions, and BW Verlag.

\section{Unit groups discussed}

Approximately 100 unit groups were rated in this meeting. The unit groups were clustered by sectors in the following categories: science, engineering, architecture \& design, ICTS, clerks, sales, security, agriculture, farming \& fishery, construction, painting, building, metal work, artisans, and operators. 


\section{Main points of discussion}

The preliminary consensus prior to this meeting was very high. There was unanimous agreement on 37 unit groups for numeracy and 30 for literacy, and agreement was almost perfect (half a level difference) in 38 cases for numeracy and 51 for literacy. There was one level difference for 15 unit groups for numeracy and 19 for literacy. Finally, there was more major disagreement on only 16 unit groups for numeracy and 6 for literacy. Following the same procedure as for previous meetings, only those unit groups for which there was some disagreement were discussed. A full summary of the ratings discussed during this meeting is available upon request from the authors.

Overall, the discussion was efficient and most ratings were straightforward after analysing one or two unit groups within the same sub-major group. There were a handful of unit groups for which the ISCO08 description was not completely representative of the corresponding tasks nowadays, but by also considering the experts' knowledge and additional sources, ratings that reflect current skill requirements were achieved. In addition, the experts asked to review two anchor unit groups (6121 Livestock and Dairy Producers and 6221 Aquaculture Workers) due to inter-group consistency concerns that became clear after having rated other unit groups. Therefore, both unit groups were referred to the final meeting held on the $19^{\text {th }}$ of May 2020.

\subsubsection{Round 2 - Subgroup 2}

\section{Participants}

Three occupational experts participated in this online meeting on the $18^{\text {th }}$ of May 2020. Their background is the Warwick Institute for Employment Research, O*NET, and StatClass. As in previous meetings, the experts were asked to send their initial ratings to ROA researchers to be combined into preliminary ratings.

\section{Unit groups discussed}

Roughly 100 unit groups were discussed during this meeting, which were organised in clusters based on sectoral similarities. These clusters were: law, sports, health, teaching, information, social work, religion, writing \& linguistic work, creative work, administration, finance \& service, mechanics, food production, artisans, crafts, and operators.

\section{Main points of discussion}

The unit groups were discussed by clusters of occupations to ensure intra-group consistency. The consensus among the experts prior to the meeting was slightly lower compared to the other subgroup meetings, probably due to greater variation among unit groups. More concretely, for numeracy (literacy) there was a perfect match for 26 (9) unit groups, an almost perfect match (only half a level difference for one expert) for 35 (47) unit groups, and one level difference for 34 (39) unit groups. There was full disagreement (differences in skill ratings of more than one skill level between experts) for only 10 unit groups, both for literacy and numeracy. Following the same structure as previous subgroup meetings, unit groups with unanimous preliminary agreement were considered as rated and were not explicitly discussed. Overall, after each expert explained his or her arguments, consensus was achieved swiftly. The main sources of disagreement were misunderstandings on the composition of certain unit groups in the context of OECD countries, as well as heterogeneity within unit groups. The group discussion helped to reach a better understanding of the unit groups, thus facilitating 
agreement on the ratings. Nonetheless, some doubts remained regarding one unit group (2261 Dentists), which was therefore referred to the final meeting. Moreover, after rating related unit groups, the anchor unit group 8141 Rubber Products Machine Operators was also referred to the final meeting, due to consistency concerns. A detailed description of discussions on specific ratings is available upon request from the authors.

\subsubsection{Round 2-Plenary meeting}

\section{Participants}

All the occupational experts and the literacy and numeracy experts attended the plenary meeting, which was held online on the $19^{\text {th }}$ of May 2020.

\section{Unit groups discussed}

The main objective of this meeting was to review four unit groups for which there were doubts during the subgroup meetings, three of them being anchor unit groups. Moreover, the "Not Elsewhere Classified" unit groups were also rated during this meeting.

\section{Main points of discussion}

Three anchor unit groups were revisited during the final meeting due to potential inter-group consistency issues. Regarding 6121 Livestock and Dairy Producers, the rating for literacy was increased given the safety regulations that workers have to read, while the rating for numeracy was decreased, as the requirements were lower than those for other unit groups that received the same original rating. Having rediscussed this unit group, the experts confirmed the same numeracy rating for 6221 Aquaculture Workers, given the similarities between them.

The concerns regarding 8141 Rubber Products Machine Operators were caused by minor inconsistencies between subgroups, as one subgroup rated very similar unit groups with a lower literacy level, while the other rated the remaining related unit groups with a higher level. Therefore, the discussion was focused on the entire sub-major group 81 Stationary Plant and Related Operators. Machine operation has become automated and the ISCO-08 description is not completely representative anymore, given that automation has removed the weighting and measuring part, even though workers still need to read the machine tools setup. In the end, the original rating of the anchor was confirmed and applied to the majority of related unit groups, with two exceptions of unit groups that have lower requirements.

The last unit group to revisit during the final meeting was 2261 Dentists, as some experts argued that the numeracy rating should be higher, considering that the knowledge and prerequisites are very high, and the unit group is very similar to unit groups with other medical professions. However, the highest level of numeracy (Level 5) requires the understanding, use and application of high level, formal, and abstract mathematics, which is not a requirement for this unit group. Therefore, after consulting with the complete group and particularly the numeracy expert, the original rating was maintained.

Additionally, there was a discussion regarding the "Not Elsewhere Classified" unit groups, in other words, the unit groups that comprise the job titles that could not be classified in any other category. Given the nature of these unit groups, they had received a preliminary rating, based on the most common rating within the corresponding sub-major group. In the plenary meeting, experts were asked 
to confirm these ratings, or to propose an alternative if needed. In the majority of the cases, the experts agreed with the preliminary results. When this was not the case, the main reason was heterogeneity within the unit group. As a solution, the experts applied the combined ratings (e.g. level $1+2$ ) that had been designated for such cases. A detailed description of the discussions on the unit groups covered during this plenary meeting is available upon request from the authors.

After this meeting, ratings of the literacy and numeracy requirements for all ISCO-08 4-digit unit groups were complete. In addition, to ensure inter-group consistency, we ranked all unit groups from highest level to lowest level of literacy and numeracy. Then, we asked all occupational and domain experts by email to review the ratings and to confirm their consistency. No further changes were necessary, thus verifying the inter-group and intra-group consistency of the ratings.

\subsection{Final evaluation session}

\section{Participants}

All but one of the occupational experts and both the literacy and numeracy experts attended the final evaluation session, which was held online on the $5^{\text {th }}$ of August 2020. This meeting was also attended by representatives from the OECD and the Dutch Ministry of Education, Culture and Science.

\section{Main points of discussion}

The main objective of this meeting was to evaluate the process, to summarize the main strengths and limitations of the Job Analysis Method and its application to skill mismatch, and to discuss future steps. The most important points that arose from this discussion are reported in Section 6 below. The participants were also given the opportunity to read a draft version of this report in advance of the meeting, and to share their feedback with us. Also, the experts were given a final opportunity to revisit the ratings of the skill requirements of any of the unit groups. Two cases were brought up for discussion: unit group 1113 (Traditional Chiefs and Heads of Villages), and the unit groups in sub-major group 81 (Stationary Plant and Machine Operators). In the end, it was agreed not to change the skill requirement ratings of these unit groups, but to further clarify in this report how the experts arrived at these ratings.

\section{Overview of the final skill ratings}

As described in the previous section, after applying the Job Analysis Method through a step-by-step rating process, we have reached agreement on the final literacy and numeracy skill requirements for all 4-digit unit groups from the ISCO-08 classification. A full overview of the final literacy and numeracy skill ratings is shown in Table 1, which appears at the end of this report (pp.26-41). The unit groups are ranked based on the ISCO-08 classification codes and the anchor unit groups are displayed in bold.

Finally, combining the information on all ISCO-08 unit groups from all the meetings presented above, we present a summary of the overall level of consensus in the initial ratings among the experts in Figure 3 (excluding anchor unit groups and "Not Elsewhere Classified" unit groups). Overall, prior to discussing the skill ratings during the meetings, there was already full agreement on the ratings for approximately one third of the unit groups, and almost full agreement (less than one level difference) in another third of the unit groups. There was one level difference among the raters in $24-28 \%$ of the 
unit groups. In addition, the experts disagreed (more than one level difference) in only 7-9\% of the unit groups. There are no major differences between literacy and numeracy in terms of agreement among the experts. All in all, in most cases initial disagreement was due to the different national and professional backgrounds of the experts, the use of different national classifications as additional resources, and the degree of heterogeneity in some unit groups. The discussions during the meetings helped to articulate the sources of disagreement, and to arrive at consensus after all. This is underlined by the fact that the experts were able to agree on the skill ratings for all 433 4-digit ISCO-08 unit groups by the end of the process. Also, we checked whether unit groups for which there was initial disagreement were more likely to receive in-between ratings or combined-level rarings in the end, and found that this was not the case.

Figure 3 Overview of the overall level of consensus among raters

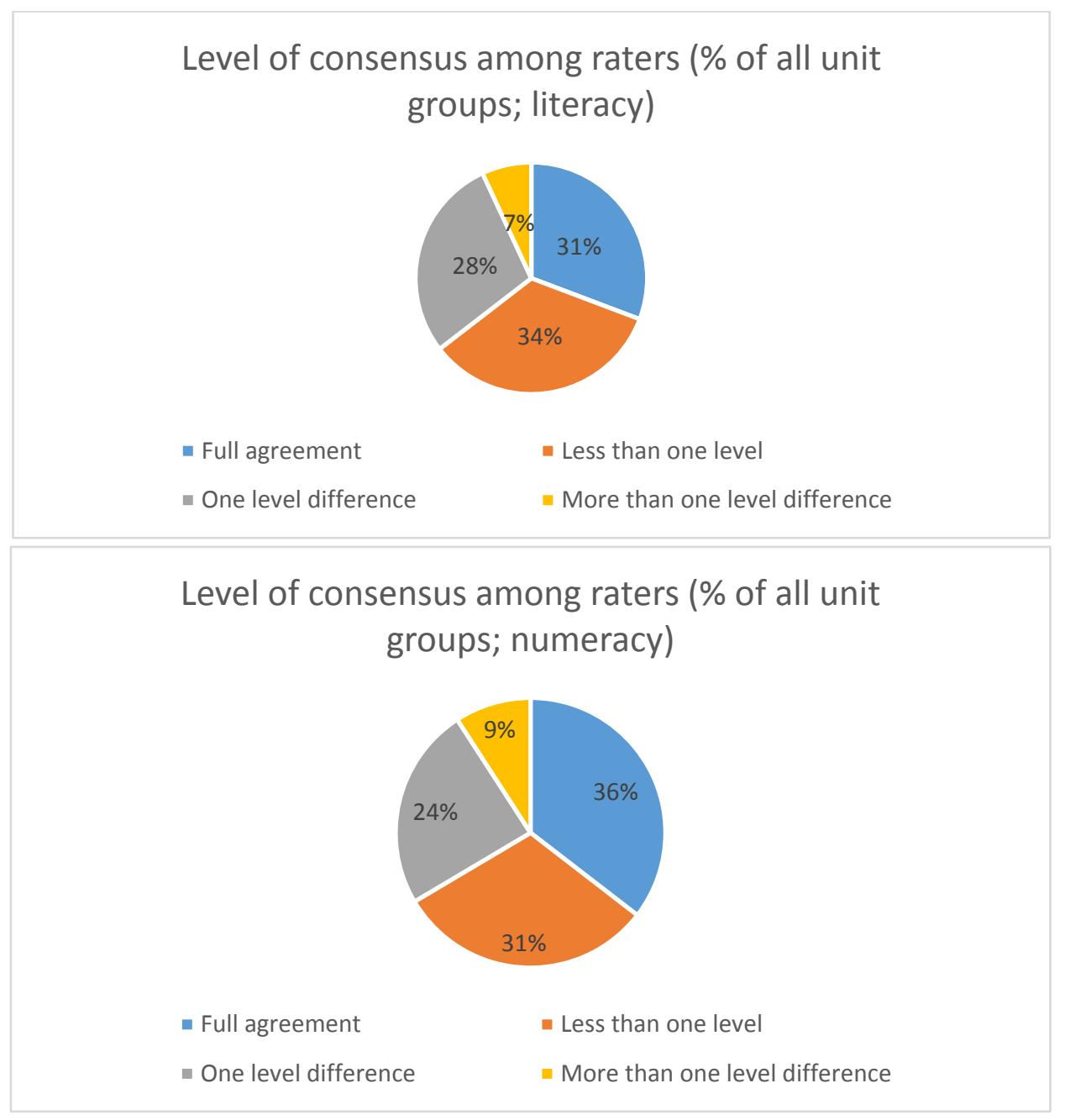

\section{Evaluation and future steps}

All in all, rating the ISCO-08 unit groups in terms of required literacy and numeracy skills has been a very valuable task, according to all the experts. Although the different national and professional backgrounds of the experts sometimes resulted in initial disagreement during the rating process, combining the perspectives from experts coming from different backgrounds and countries has been 
very helpful to ensure complete, balanced, and representative final ratings. The experts expressed their regret that it was impossible to have a physical meeting in Paris as planned initially due to the restrictions following the COVID-19 pandemic. Most importantly, this would have given the literacy and numeracy experts more time to provide training on the proficiency levels from the PIAAC framework. This would have made the initial classifications more consistent and stable. However, as the process moved forward, experts felt an increasingly clear understanding of what the concepts of literacy and numeracy entail in the PIAAC framework. Additionally, after the pilot study, the rating process quickly became more consistent and precise, as experts could compare unit groups relative to others (e.g. through the use of anchor unit groups).

The project also came with some other challenges and limitations. Given the importance of linking the ratings of the skill requirements to the skill proficiency levels in PIAAC, we were only able to cover literacy and numeracy skill requirements. Literacy and numeracy are both crucial skills, and prerequisites for acquiring both job-specific technical skills and transferable skills that support occupational mobility. Nonetheless, our results cannot necessarily be applied to other skill domains. Related to this, for some unit groups, the experts found it difficult to rate the required literacy skills without taking into account writing skills. As noted, the exclusion of writing skills was necessary to align the literacy skill requirement ratings with the literacy skill proficiency levels in the PIAAC data. Additionally, within the same unit groups, literacy and numeracy skill requirements may vary across countries, and change over time. Most importantly, developments in ICT and automatisation over the past few decades have changed the required literacy and numeracy skills in multiple occupations, reducing the requirements in some cases (e.g. by facilitating automatic calculations in spreadsheets), while at the same time increasing the requirements in other cases (e.g. by leading to the increased use of email to communicate with customers). Although the experts were asked to take this into account in their ratings, it was clear during the process that these changes sometimes made it more difficult to determine appropriate ratings. Also, for some unit groups it appeared that the ISCO-08 task descriptions were outdated due to developments in ICT and automatisation. As a result, the literacy and numeracy skill requirements that resulted from this project may need to be reviewed in 5 or 10 years time to establish whether they are still accurate in light of technological changes.

The addition of the combined ratings has been very helpful to deal with heterogeneous unit groups. The combined ratings (e.g. level $1+2$ ) served a dual purpose: to provide accurate ratings for heterogeneous unit groups, as well as to distinguish them clearly for analytic use in future research based on the skill ratings derived in this project. Moreover, signaling which unit groups are heterogeneous is useful for the revision of the ISCO classification in the future, given that occupations change over time and it may be worth considering which new unit groups could be introduced. Additionally, an increasing convergence in craft occupations in groups 3 and 7 has been observed throughout the Job Analysis Method project, which is also relevant for a future update of the ISCO classification. Furthermore, identification of ISCO unit groups and occupations with high or low numeracy or literacy skill ratings may be useful to identify those unit groups, minor groups, or submajor groups that may no longer be classified at the correct ISCO skill level.

Combined ratings should not be confused with in-between ratings (e.g. level 1.5). The PIAAC framework considers five proficiency levels plus a below level 1 , each of them comprising a broad range of items in terms of difficulty. Therefore, introducing in-between ratings transforms the PIAAC scale into a scale of 11 levels (without taking into consideration combined ratings), hence increasing 
the level of detail of the skill requirements. Incorporating combined and in-between ratings will thus add precision to the estimation of skill mismatch in future research, as the skill requirements will be more representative of the wide and fine-grained range of skills required across occupations than in previous analyses. Nonetheless, it should also be acknowledged that there is still wide variation in the actual skill levels within the PIAAC skill categories, and that the use of in-between ratings only partially addresses this. Additionally, rating the "Not Elsewhere Classified" unit groups has been challenging given that they are inherently heterogeneous in nature. However, the rating strategy we have followed for these unit groups offered a good balance between efficiency, accuracy, and feasibility, and the experts were able to find agreement on the ratings for each of these unit groups as well.

In conclusion, applying the Job Analysis Method to skill mismatch by rating the skill requirements of the occupational unit groups in the ISCO-08 classification has helped to determine the critical literacy and numeracy skill requirements to carry out the tasks for the jobs in each unit group. As a consequence, this project contributes to the literature by applying this method to skill mismatch, thus enabling an unbiased analysis of skill mismatch estimates in future research using the PIAAC data on skill proficiency. Additionally, this project distinguishes itself by the incorporation of combined ratings to treat heterogeneous unit groups, as well as in-between ratings to increase the level of detail of the skill requirements. All in all, the Job Analysis Method has been a rewarding and fruitful exercise that can open the door for new discussions and developments, not only in the field of skill mismatch, but also in the revision of ISCO as well as in the definition and conceptualisation of literacy and numeracy skills in the PIAAC framework. 
Table 1 Literacy and numeracy skill requirements of the ISCO-08 unit groups

\begin{tabular}{|c|c|c|c|}
\hline ISCO-08 & Occupation & Literacy & Numeracy \\
\hline 1111 & Legislators & Level 5 & Level 4 \\
\hline 1112 & Senior Government Officials & Level 5 & Level 4 \\
\hline 1113 & Traditional Chiefs and Heads of Villages & Level 3 & Level 3 \\
\hline 1114 & $\begin{array}{l}\text { Senior Officials of Special-interest } \\
\text { Organizations }\end{array}$ & Level 4.5 & Level 4 \\
\hline 1120 & Managing Directors and Chief Executives & Level 5 & Level 4 \\
\hline 1211 & Finance Managers & Level 5 & Level 4 \\
\hline 1212 & Human Resource Managers & Level 4.5 & Level 4 \\
\hline 1213 & Policy and Planning Managers & Level 5 & Level 4 \\
\hline 1219 & $\begin{array}{l}\text { Business Services and Administration } \\
\text { Managers Not Elsewhere Classified }\end{array}$ & Level 4 & Level 4 \\
\hline 1221 & Sales and Marketing Managers & Level 4.5 & Level 4 \\
\hline 1222 & Advertising and Public Relations Managers & Level 4.5 & Level 4 \\
\hline 1223 & Research and Development Managers & Level $4+5$ & Level $4+5$ \\
\hline 1311 & Agricultural and Forestry Production Managers & Level 4.5 & Level 4.5 \\
\hline 1312 & $\begin{array}{l}\text { Aquaculture and Fisheries Production } \\
\text { Managers }\end{array}$ & Level 4.5 & Level 4.5 \\
\hline 1321 & Manufacturing Managers & Level 4.5 & Level 4 \\
\hline 1322 & Mining Managers & Level 4.5 & Level 4 \\
\hline 1323 & Construction Managers & Level 4.5 & Level 4 \\
\hline 1324 & Supply, Distribution and Related Managers & Level 4.5 & Level 4 \\
\hline 1330 & $\begin{array}{l}\text { Information and Communications Technology } \\
\text { Services Managers }\end{array}$ & Level $4+5$ & Level $3+4$ \\
\hline 1341 & Child Care Services Managers & Level 4 & Level 4 \\
\hline 1342 & Health Services Managers & Level 5 & Level 4 \\
\hline 1343 & Aged Care Services Managers & Level 4 & Level 4 \\
\hline 1344 & Social Welfare Managers & Level 4 & Level 4 \\
\hline 1345 & Education Managers & Level $4+5$ & Level $3+4$ \\
\hline 1346 & $\begin{array}{l}\text { Financial and Insurance Services Branch } \\
\text { Managers }\end{array}$ & Level 4 & Level 4 \\
\hline 1349 & $\begin{array}{l}\text { Professional Services Managers Not Elsewhere } \\
\text { Classified }\end{array}$ & Level $4+5$ & Level 4 \\
\hline
\end{tabular}




\begin{tabular}{|c|c|c|c|}
\hline 1411 & Hotel Managers & Level $3+4$ & Level $3+4$ \\
\hline 1412 & Restaurant Managers & Level 3 & Level 3 \\
\hline 1420 & Retail and Wholesale Trade Managers & Level 3.5 & Level 4 \\
\hline 1431 & $\begin{array}{l}\text { Sports, Recreation and Cultural Centre } \\
\text { Managers }\end{array}$ & Level $3+4$ & Level $3+4$ \\
\hline 1439 & Services Managers Not Elsewhere Classified & Level $3+4$ & Level $3+4$ \\
\hline 2111 & Physicists and Astronomers & Level 4.5 & Level 5 \\
\hline 2112 & Meteorologists & Level 4.5 & Level 5 \\
\hline 2113 & Chemists & Level 4.5 & Level 5 \\
\hline 2114 & Geologists and Geophysicists & Level 4.5 & Level 5 \\
\hline 2120 & Mathematicians, Actuaries and Statisticians & Level 4.5 & Level 5 \\
\hline 2131 & $\begin{array}{l}\text { Biologists, Botanists, Zoologists and Related } \\
\text { Professionals }\end{array}$ & Level 4.5 & Level 4.5 \\
\hline 2132 & Farming, Forestry and Fisheries Advisers & Level 4.5 & Level 4 \\
\hline 2133 & Environmental and Protection Professionals & Level 4.5 & Level 4.5 \\
\hline 2141 & Industrial and Production Engineers & Level 4.5 & Level 4.5 \\
\hline 2142 & Civil Engineers & Level 4.5 & Level 5 \\
\hline 2143 & Environmental Engineers & Level 4.5 & Level 5 \\
\hline 2144 & Mechanical Engineers & Level 4.5 & Level 5 \\
\hline 2145 & Chemical Engineers & Level 4.5 & Level 5 \\
\hline 2146 & $\begin{array}{l}\text { Mining Engineers, Metallurgists and Related } \\
\text { Professionals }\end{array}$ & Level 4.5 & Level 5 \\
\hline 2149 & $\begin{array}{l}\text { Engineering Professionals Not Elsewhere } \\
\text { Classified }\end{array}$ & Level 4.5 & Level 5 \\
\hline 2151 & Electrical Engineers & Level 4.5 & Level 5 \\
\hline 2152 & Electronics Engineers & Level 4.5 & Level 5 \\
\hline 2153 & Telecommunications Engineers & Level 4.5 & Level 5 \\
\hline 2161 & Building Architects & Level 4.5 & Level 5 \\
\hline 2162 & Landscape Architects & Level 4.5 & Level 4 \\
\hline 2163 & Product and Garment Designers & Level 4 & Level $3+4$ \\
\hline 2164 & Town and Traffic Planners & Level 4.5 & Level 4.5 \\
\hline 2165 & Cartographers and Surveyors & Level 4.5 & Level 4.5 \\
\hline
\end{tabular}




\begin{tabular}{|c|c|c|c|}
\hline 2166 & Graphic and Multimedia Designers & Level 4 & Level 3.5 \\
\hline 2211 & Generalist Medical Practitioners & Level 5 & Level 4.5 \\
\hline 2212 & Specialist Medical Practitioners & Level 5 & Level 5 \\
\hline 2221 & Nursing Professionals & Level $3+4$ & Level 4 \\
\hline 2222 & Midwifery Professionals & Level 4 & Level 4 \\
\hline 2230 & $\begin{array}{l}\text { Traditional and Complementary Medicine } \\
\text { Professionals }\end{array}$ & Level 4 & Level 4 \\
\hline 2240 & Paramedical Practitioners & Level 4 & Level 4 \\
\hline 2250 & Veterinarians & Level 5 & Level 5 \\
\hline 2261 & Dentists & Level 5 & Level 4.5 \\
\hline 2262 & Pharmacists & Level 5 & Level 5 \\
\hline 2263 & $\begin{array}{l}\text { Environmental and Occupational Health and } \\
\text { Hygiene Professionals }\end{array}$ & Level 4 & Level 4.5 \\
\hline 2264 & Physiotherapists & Level 4 & Level 3.5 \\
\hline 2265 & Dieticians and Nutritionists & Level 4 & Level 4 \\
\hline 2266 & Audiologists and Speech Therapists & Level 4 & Level 4 \\
\hline 2267 & Optometrists and Ophthalmic Opticians & Level 4 & Level 4 \\
\hline 2269 & Health Professionals Not Elsewhere Classified & Level 4 & Level 4 \\
\hline 2310 & University and Higher Education Teachers & Level 5 & Level $4+5$ \\
\hline 2320 & Vocational Education Teachers & Level 4 & Level $3+4$ \\
\hline 2330 & Secondary Education Teachers & Level 4 & Level $3+4$ \\
\hline 2341 & Primary School Teachers & Level 3.5 & Level 3 \\
\hline 2342 & Early Childhood Educators & Level 3.5 & Level 2.5 \\
\hline 2351 & Education Methods Specialists & Level 5 & Level 4 \\
\hline 2352 & Special Needs Teachers & Level 4 & Level 3 \\
\hline 2353 & Other Language Teachers & Level 3.5 & Level 2.5 \\
\hline 2354 & Other Music Teachers & Level $3+4$ & Level 3 \\
\hline 2355 & Other Arts Teachers & Level $3+4$ & Level 2.5 \\
\hline 2356 & Information Technology Trainers & Level 4 & Level 4 \\
\hline 2359 & $\begin{array}{l}\text { Teaching Professionals Not Elsewhere } \\
\text { Classified }\end{array}$ & Level $3+4$ & Level $3+4$ \\
\hline 2411 & Accountants & Level $4+5$ & Level $4+5$ \\
\hline 2412 & Financial and Investment Advisers & Level $4+5$ & Level $4+5$ \\
\hline 2413 & Financial Analysts & Level 5 & Level 4.5 \\
\hline 2421 & Management and Organization Analysts & Level 5 & Level 4 \\
\hline
\end{tabular}




\begin{tabular}{|c|c|c|c|}
\hline 2422 & Policy Administration Professionals & Level 5 & Level 4 \\
\hline 2423 & Personnel and Careers Professionals & Level 4 & Level 3 \\
\hline 2424 & Training and Staff Development Professionals & Level 4 & Level 3 \\
\hline 2431 & Advertising and Marketing Professionals & Level 4 & Level 3.5 \\
\hline 2432 & Public Relations Professionals & Level 4 & Level 3.5 \\
\hline 2433 & $\begin{array}{l}\text { Technical and Medical Sales Professionals } \\
\text { (excluding ICT) }\end{array}$ & Level 4 & Level 4 \\
\hline 2434 & $\begin{array}{l}\text { Information and Communications Technology } \\
\text { Sales Professionals }\end{array}$ & Level 4 & Level 4 \\
\hline 2511 & Systems Analysts & Level 4.5 & Level 4.5 \\
\hline 2512 & Software Developers & Level 4.5 & Level 4 \\
\hline 2513 & Web and Multimedia Developers & Level 4.5 & Level 4 \\
\hline 2514 & Applications Programmers & Level 4.5 & Level 4 \\
\hline 2519 & $\begin{array}{l}\text { Software and Applications Developers and } \\
\text { Analysts Not Elsewhere Classified }\end{array}$ & Level 4.5 & Level 4 \\
\hline 2521 & Database Designers and Administrators & Level 4 & Level 4 \\
\hline 2522 & Systems Administrators & Level 3.5 & Level 3.5 \\
\hline 2523 & Computer Network Professionals & Level 4 & Level 4 \\
\hline 2529 & $\begin{array}{l}\text { Database and Network Professionals Not } \\
\text { Elsewhere Classified }\end{array}$ & Level 4 & Level 4 \\
\hline 2611 & Lawyers & Level 5 & Level 4 \\
\hline 2612 & Judges & Level 5 & Level 4 \\
\hline 2619 & Legal Professionals Not Elsewhere Classified & Level 5 & Level 4 \\
\hline 2621 & Archivists and Curators & Level 5 & Level 3.5 \\
\hline 2622 & $\begin{array}{l}\text { Librarians and Related Information } \\
\text { Professionals }\end{array}$ & Level 5 & Level 3.5 \\
\hline 2631 & Economists & Level 5 & Level 5 \\
\hline 2632 & $\begin{array}{l}\text { Sociologists, Anthropologists and Related } \\
\text { Professionals }\end{array}$ & Level 5 & Level 4 \\
\hline 2633 & Philosophers, Historians and Political Scientists & Level 5 & Level 4 \\
\hline 2634 & Psychologists & Level 5 & Level 4.5 \\
\hline 2635 & Social Work and Counselling Professionals & Level $4+5$ & Level $3+4$ \\
\hline
\end{tabular}




\begin{tabular}{|c|c|c|c|}
\hline 2636 & Religious Professionals & Level 5 & Level 3 \\
\hline 2641 & Authors and Related Writers & Level $4+5$ & Level 3 \\
\hline 2642 & Journalists & Level 5 & Level 3 \\
\hline 2643 & Translators, Interpreters and Other Linguists & Level 5 & Level 2.5 \\
\hline 2651 & Visual Artists & Level $3+4$ & Level 2 \\
\hline 2652 & Musicians, Singers and Composers & Level $3+4$ & Level $2+3$ \\
\hline 2653 & Dancers and Choreographers & Level $3+4$ & Level 2 \\
\hline 2654 & $\begin{array}{l}\text { Film, Stage and Related Directors and } \\
\text { Producers }\end{array}$ & Level 4.5 & Level $3+4$ \\
\hline 2655 & Actors & Level $3+4$ & Level 1 \\
\hline 2656 & $\begin{array}{l}\text { Announcers on Radio, Television and Other } \\
\text { Media }\end{array}$ & Level $3+4$ & Level $2+3$ \\
\hline 2659 & $\begin{array}{l}\text { Creative and Performing Artists Not Elsewhere } \\
\text { Classified }\end{array}$ & Level $2+3$ & Level $1+2$ \\
\hline 3111 & Chemical and Physical Science Technicians & Level 3 & Level 4 \\
\hline 3112 & Civil Engineering Technicians & Level 3 & Level 4 \\
\hline 3113 & Electrical Engineering Technicians & Level 3 & Level 4 \\
\hline 3114 & Electronics Engineering Technicians & Level 3 & Level 4 \\
\hline 3115 & Mechanical Engineering Technicians & Level 3 & Level 4 \\
\hline 3116 & Chemical Engineering Technicians & Level 3 & Level 4 \\
\hline 3117 & Mining and Metallurgical Technicians & Level 3 & Level 4 \\
\hline 3118 & Draughtspersons & Level 3 & Level 4 \\
\hline 3119 & $\begin{array}{l}\text { Physical and Engineering Science Technicians } \\
\text { Not Elsewhere Classified }\end{array}$ & Level 3 & Level 4 \\
\hline 3121 & Mining Supervisors & Level 3 & Level 3 \\
\hline 3122 & Manufacturing Supervisors & Level 3 & Level 3 \\
\hline 3123 & Construction Supervisors & Level 3 & Level 3 \\
\hline 3131 & Power Production Plant Operators & Level 3 & Level 3.5 \\
\hline 3132 & $\begin{array}{l}\text { Incinerator and Water Treatment Plant } \\
\text { Operators }\end{array}$ & Level 3 & Level 3.5 \\
\hline 3133 & Chemical Processing Plant Controllers & Level 3 & Level 3.5 \\
\hline 3134 & $\begin{array}{l}\text { Petroleum and Natural Gas Refining Plant } \\
\text { Operators }\end{array}$ & Level 3 & Level 3.5 \\
\hline 3135 & Metal Production Process Controllers & Level 2.5 & Level 3 \\
\hline
\end{tabular}




\begin{tabular}{|c|c|c|c|}
\hline 3139 & $\begin{array}{l}\text { Process Control Technicians Not Elsewhere } \\
\text { Classified }\end{array}$ & Level 3 & Level 3.5 \\
\hline 3141 & Life Science Technicians (excluding Medical) & Level 3 & Level 4 \\
\hline 3142 & Agricultural Technicians & Level 3 & Level 4 \\
\hline 3143 & Forestry Technicians & Level 3 & Level 4 \\
\hline 3151 & Ships' Engineers & Level 3 & Level 4 \\
\hline 3152 & Ships' Deck Officers and Pilots & Level 3 & Level 4 \\
\hline 3153 & $\begin{array}{l}\text { Aircraft Pilots and Related Associate } \\
\text { Professionals }\end{array}$ & Level 3 & Level 4 \\
\hline 3154 & Air Traffic Controllers & Level 3 & Level 4 \\
\hline 3155 & Air Traffic Safety Electronics Technicians & Level 3 & Level 4 \\
\hline 3211 & $\begin{array}{l}\text { Medical Imaging and Therapeutic Equipment } \\
\text { Technicians }\end{array}$ & Level 3 & Level $3+4$ \\
\hline 3212 & Medical and Pathology Laboratory Technicians & Level 3 & Level 4 \\
\hline 3213 & Pharmaceutical Technicians and Assistants & Level 3 & Level 3.5 \\
\hline 3214 & Medical and Dental Prosthetic Technicians & Level 2.5 & Level 3 \\
\hline 3221 & Nursing Associate professionals & Level 3 & Level 3 \\
\hline 3222 & Midwifery Associate professionals & Level 3 & Level 3 \\
\hline 3230 & $\begin{array}{l}\text { Traditional and Complementary Medicine } \\
\text { Associate Professionals }\end{array}$ & Level 3 & Level 2.5 \\
\hline 3240 & Veterinary Technicians and Assistants & Level 3 & Level 3 \\
\hline 3251 & Dental Assistants and Therapists & Level $2+3$ & Level 3 \\
\hline 3252 & $\begin{array}{l}\text { Medical Records and Health Information } \\
\text { Technicians }\end{array}$ & Level 3.5 & Level 3 \\
\hline 3253 & Community Health Workers & Level 3 & Level 3 \\
\hline 3254 & Dispensing Opticians & Level 2.5 & Level 3 \\
\hline 3255 & Physiotherapy Technicians and Assistants & Level 2.5 & Level 3 \\
\hline 3256 & Medical Assistants & Level 3 & Level 3 \\
\hline 3257 & $\begin{array}{l}\text { Environmental and Occupational Health } \\
\text { Inspectors and Associates }\end{array}$ & Level 3 & Level 3.5 \\
\hline 3258 & Ambulance Workers & Level $2+3$ & Level $2+3$ \\
\hline 3259 & $\begin{array}{l}\text { Health Associate Professionals Not Elsewhere } \\
\text { Classified }\end{array}$ & Level 3 & Level 3 \\
\hline
\end{tabular}




\begin{tabular}{|c|c|c|c|}
\hline 3311 & Securities and Finance Dealers and Brokers & Level 5 & Level 4 \\
\hline 3312 & Credit and Loans Officers & Level 3 & Level 3 \\
\hline 3313 & Accounting Associate Professionals & Level 3 & Level 3 \\
\hline 3314 & $\begin{array}{l}\text { Statistical, Mathematical and Related } \\
\text { Associate Professionals }\end{array}$ & Level 3 & Level 4 \\
\hline 3315 & Valuers and Loss Assessors & Level 3 & Level 3 \\
\hline 3321 & Insurance Representatives & Level 3 & Level 3 \\
\hline 3322 & Commercial Sales Representatives & Level 3 & Level 3 \\
\hline 3323 & Buyers & Level 4 & Level 4 \\
\hline 3324 & Trade Brokers & Level 3 & Level 3.5 \\
\hline 3331 & Clearing and Forwarding Agents & Level 2 & Level 2 \\
\hline 3332 & Conference and Event Planners & Level 2.5 & Level 2.5 \\
\hline 3333 & Employment Agents and Contractors & Level 2 & Level 1.5 \\
\hline 3334 & Real Estate Agents and Property Managers & Level 3 & Level 3 \\
\hline 3339 & $\begin{array}{l}\text { Business Services Agents Not Elsewhere } \\
\text { Classified }\end{array}$ & Level $2+3$ & Level $2+3$ \\
\hline 3341 & Office Supervisors & Level 2.5 & Level 2 \\
\hline 3342 & Legal Secretaries & Level 3 & Level 2.5 \\
\hline 3343 & Administrative and Executive Secretaries & Level 2.5 & Level 2 \\
\hline 3344 & Medical Secretaries & Level 3 & Level 2.5 \\
\hline 3351 & Customs and Border Inspectors & Level 3 & Level 3 \\
\hline 3352 & Government Tax and Excise Officials & Level 3 & Level 3 \\
\hline 3353 & Government Social Benefits Officials & Level 3 & Level 3 \\
\hline 3354 & Government Licensing Officials & Level 3 & Level 3 \\
\hline 3355 & Police Inspectors and Detectives & Level 4 & Level 3 \\
\hline 3359 & $\begin{array}{l}\text { Government Regulatory Associate } \\
\text { Professionals Not Elsewhere Classified }\end{array}$ & Level 3 & Level 3 \\
\hline 3411 & Legal and Related Associate Professionals & Level 3 & Level 3 \\
\hline 3412 & Social Work Associate Professionals & Level 3 & Level $2+3$ \\
\hline 3413 & Religious Associate Professionals & Level 2 & Level 1 \\
\hline 3421 & Athletes and Sports Players & Level $1+2$ & Level $1+2$ \\
\hline 3422 & Sports Coaches, Instructors and Officials & Level $2+3$ & Level $2+3$ \\
\hline
\end{tabular}




\begin{tabular}{|c|c|c|c|}
\hline 3423 & $\begin{array}{l}\text { Fitness and Recreation Instructors and } \\
\text { Programme Leaders }\end{array}$ & Level 2 & Level $2+3$ \\
\hline 3431 & Photographers & Level $2+3$ & Level 3 \\
\hline 3432 & Interior Designers and Decorators & Level $2+3$ & Level 3.5 \\
\hline 3433 & Gallery, Museum and Library Technicians & Level 2.5 & Level 2.5 \\
\hline 3434 & Chefs & Level 2.5 & Level 3 \\
\hline 3435 & $\begin{array}{l}\text { Other Artistic and Cultural Associate } \\
\text { Professionals }\end{array}$ & Level $2+3$ & Level $2+3$ \\
\hline 3511 & $\begin{array}{l}\text { Information and Communications Technology } \\
\text { Operations Technicians }\end{array}$ & Level 3 & Level 3 \\
\hline 3512 & $\begin{array}{l}\text { Information and Communications Technology } \\
\text { User Support Technicians }\end{array}$ & Level 3 & Level 3 \\
\hline 3513 & Computer Network and Systems Technicians & Level 3 & Level 3 \\
\hline 3514 & Web Technicians & Level 3 & Level 3 \\
\hline 3521 & Broadcasting and Audiovisual Technicians & Level 3 & Level 3 \\
\hline 3522 & Telecommunications Engineering Technicians & Level 3 & Level 4 \\
\hline 4110 & General Office Clerks & Level 2 & Level 2.5 \\
\hline 4120 & Secretaries (general) & Level 2 & Level 2 \\
\hline 4131 & Typists and Word Processing Operators & Level 2 & Level 1.5 \\
\hline 4132 & Data Entry Clerks & Level 1.5 & Level 2.5 \\
\hline 4211 & Bank Tellers and Related Clerks & Level 2 & Level 3 \\
\hline 4212 & $\begin{array}{l}\text { Bookmakers, Croupiers and Related Gaming } \\
\text { Workers }\end{array}$ & Level $1+2$ & Level $3+4$ \\
\hline 4213 & Pawnbrokers and Money-lenders & Level 1.5 & Level 3 \\
\hline 4214 & Debt Collectors and Related Workers & Level 2 & Level 2.5 \\
\hline 4221 & Travel Consultants and Clerks & Level 2.5 & Level 2 \\
\hline 4222 & Contact Centre Information Clerks & Level 2 & Level 2 \\
\hline 4223 & Telephone Switchboard Operators & Level 1 & Level 1 \\
\hline 4224 & Hotel Receptionists & Level 1.5 & Level 1 \\
\hline 4225 & Inquiry Clerks & Level 1 & Level 1 \\
\hline 4226 & Receptionists (general) & Level 1 & Level 1 \\
\hline 4227 & Survey and Market Research Interviewers & Level 2 & Level 1 \\
\hline 4229 & $\begin{array}{l}\text { Client Information Workers Not Elsewhere } \\
\text { Classified }\end{array}$ & Level $1+2$ & Level $1+2$ \\
\hline 4311 & Accounting and Bookkeeping Clerks & Level 2 & Level 2.5 \\
\hline
\end{tabular}




\begin{tabular}{|c|c|c|c|}
\hline 4312 & Statistical, Finance and Insurance Clerks & Level 2 & Level 2.5 \\
\hline 4313 & Payroll Clerks & Level 2 & Level 2.5 \\
\hline 4321 & Stock Clerks & Level 1 & Level 2 \\
\hline 4322 & Production Clerks & Level 2 & Level 2 \\
\hline 4323 & Transport Clerks & Level 2 & Level 2 \\
\hline 4411 & Library Clerks & Level 2 & Level 1.5 \\
\hline 4412 & Mail Carriers and Sorting Clerks & Level 2 & Level 1.5 \\
\hline 4413 & Coding, proofreading and related clerks & Level 2.5 & Level 1.5 \\
\hline 4414 & Scribes and Related Workers & Level 2 & Level 1 \\
\hline 4415 & Filing and Copying Clerks & Level 2 & Level 1.5 \\
\hline 4416 & Personnel Clerks & Level 2 & Level 1.5 \\
\hline 4419 & $\begin{array}{l}\text { Clerical Support Workers Not Elsewhere } \\
\text { Classified }\end{array}$ & Level 2 & Level 1.5 \\
\hline 5111 & Travel Attendants and Travel Stewards & Level 1 & Level 1.5 \\
\hline 5112 & Transport Conductors & Level 1 & Level 1 \\
\hline 5113 & Travel Guides & Level $2+3$ & Level 2 \\
\hline 5120 & Cooks & Level 1 & Level 2 \\
\hline 5131 & Waiters & Level 1 & Level 1.5 \\
\hline 5132 & Bartenders & Level 1 & Level 2 \\
\hline 5141 & Hairdressers & Level $0+1$ & Level $1+2$ \\
\hline 5142 & Beauticians and Related Workers & Level $0+1$ & Level $1+2$ \\
\hline 5151 & $\begin{array}{l}\text { Cleaning and Housekeeping Supervisors in } \\
\text { Offices, Hotels and Other Establishments }\end{array}$ & Level 1 & Level 1 \\
\hline 5152 & Domestic Housekeepers & Level 0 & Level 0 \\
\hline 5153 & Building Caretakers & Level 0 & Level 0 \\
\hline 5161 & $\begin{array}{l}\text { Astrologers, Fortune-tellers and Related } \\
\text { Workers }\end{array}$ & Level 1.5 & Level 1 \\
\hline 5162 & Companions and Valets & Level 1.5 & Level 1 \\
\hline 5163 & Undertakers and Embalmers & Level $1+2$ & Level 2 \\
\hline 5164 & Pet Groomers and Animal Care Workers & Level 1.5 & Level 1 \\
\hline 5165 & Driving Instructors & Level 2 & Level 2 \\
\hline 5169 & $\begin{array}{l}\text { Personal Services Workers Not Elsewhere } \\
\text { Classified }\end{array}$ & Level $0+1$ & Level $0+1$ \\
\hline 5211 & Stall and Market salespersons & Level 1 & Level 1.5 \\
\hline 5212 & Street Food Salespersons & Level 0.5 & Level 1 \\
\hline 5221 & Shopkeepers & Level 2.5 & Level 3 \\
\hline
\end{tabular}




\begin{tabular}{|c|c|c|c|}
\hline 5222 & Shop Supervisors & Level 2 & Level 2 \\
\hline 5223 & Shop Sales Assistants & Level 1 & Level $1+2$ \\
\hline 5230 & Cashiers and Ticket Clerks & Level 1 & Level 2 \\
\hline 5241 & Fashion and Other Models & Level 0 & Level 0 \\
\hline 5242 & Sales Demonstrators & Level 1 & Level 0.5 \\
\hline 5243 & Door-to-door salespersons & Level 1 & Level 1 \\
\hline 5244 & Contact Centre Salespersons & Level 1.5 & Level 1 \\
\hline 5245 & Service Station Attendants & Level 1 & Level 1.5 \\
\hline 5246 & Food Service Counter Attendants & Level 1 & Level 1 \\
\hline 5249 & Sales Workers Not Elsewhere Classified & Level 1 & Level $1+2$ \\
\hline 5311 & Child Care Workers & Level 2.5 & Level 1.5 \\
\hline 5312 & Teachers' aides & Level 2.5 & Level 1.5 \\
\hline 5321 & Health Care Assistants & Level 2 & Level 1.5 \\
\hline 5322 & Home-based Personal Care Workers & Level 2.5 & Level 2 \\
\hline 5329 & $\begin{array}{l}\text { Personal Care Workers in Health Services Not } \\
\text { Elsewhere Classified }\end{array}$ & Level $1+2$ & Level $1+2$ \\
\hline 5411 & Firefighters & Level 2.5 & Level 2 \\
\hline 5412 & Police Officers & Level 3 & Level 2.5 \\
\hline 5413 & Prison Guards & Level 2 & Level 1 \\
\hline 5414 & Security Guards & Level 1.5 & Level 1 \\
\hline 5419 & $\begin{array}{l}\text { Protective Services Workers Not Elsewhere } \\
\text { Classified }\end{array}$ & Level 1 & Level 1 \\
\hline 6111 & Field Crop and Vegetable Growers & Level 2 & Level 3 \\
\hline 6112 & Tree and Shrub Crop Growers & Level 2 & Level 3 \\
\hline 6113 & Gardeners; Horticultural and Nursery Growers & Level 2 & Level 3 \\
\hline 6114 & Mixed Crop Growers & Level 2 & Level 3 \\
\hline 6121 & Livestock and Dairy Producers & Level 3 & Level 3 \\
\hline 6122 & Poultry Producers & Level 2.5 & Level 3 \\
\hline 6123 & Apiarists and Sericulturists & Level 2 & Level 2 \\
\hline 6129 & Animal Producers Not Elsewhere Classified & Level 2 & Level 2.5 \\
\hline 6130 & Mixed Crop and Animal Producers & Level $2+3$ & Level 3 \\
\hline 6210 & Forestry and Related Workers & Level 2 & Level 2 \\
\hline 6221 & Aquaculture Workers & Level 2 & Level 3 \\
\hline
\end{tabular}




\begin{tabular}{|c|c|c|c|}
\hline 6222 & Inland and Coastal Waters Fishery Workers & Level 2 & Level 2.5 \\
\hline 6223 & Deep-sea Fishery Workers & Level 2 & Level 2.5 \\
\hline 6224 & Hunters and Trappers & Level 1 & Level 2 \\
\hline 6310 & Subsistence Crop Farmers & Level 0 & Level 1 \\
\hline 6320 & Subsistence Livestock Farmers & Level 0 & Level 1 \\
\hline 6330 & Subsistence Mixed Crop and Livestock Farmers & Level 0 & Level 1 \\
\hline 6340 & $\begin{array}{l}\text { Subsistence Fishers, Hunters, Trappers and } \\
\text { Gatherers }\end{array}$ & Level 0 & Level 1 \\
\hline 7111 & House Builders & Level 1.5 & Level 2 \\
\hline 7112 & Bricklayers and Related Workers & Level 1.5 & Level 2 \\
\hline 7113 & $\begin{array}{l}\text { Stonemasons, Stone cutters, Splitters and } \\
\text { Carvers }\end{array}$ & Level 1.5 & Level 2 \\
\hline 7114 & $\begin{array}{l}\text { Concrete Placers, Concrete Finishers and } \\
\text { Related Workers }\end{array}$ & Level 1.5 & Level 2 \\
\hline 7115 & Carpenters and Joiners & Level 1.5 & Level 2 \\
\hline 7119 & $\begin{array}{l}\text { Building Frame and Related Trades Workers } \\
\text { Not Elsewhere Classified }\end{array}$ & Level 1.5 & Level 1.5 \\
\hline 7121 & Roofers & Level 1.5 & Level 2 \\
\hline 7122 & Floor Layers and Tile Setters & Level 1.5 & Level 2 \\
\hline 7123 & Plasterers & Level 1.5 & Level 2 \\
\hline 7124 & Insulation Workers & Level 1.5 & Level 2 \\
\hline 7125 & Glaziers & Level 1.5 & Level 2 \\
\hline 7126 & Plumbers and Pipe Fitters & Level 2 & Level 3 \\
\hline 7127 & Air Conditioning and Refrigeration Mechanics & Level 2 & Level 3 \\
\hline 7131 & Painters and Related Workers & Level 1.5 & Level 2 \\
\hline 7132 & Spray Painters and Varnishers & Level 1.5 & Level 2 \\
\hline 7133 & Building Structure Cleaners & Level 1 & Level 1 \\
\hline 7211 & Metal Moulders and Coremakers & Level 1.5 & Level 2.5 \\
\hline 7212 & Welders and Flame Cutters & Level 1.5 & Level 2 \\
\hline 7213 & Sheet Metal Workers & Level 1.5 & Level 2.5 \\
\hline 7214 & Structural Metal Preparers and Erectors & Level 1.5 & Level 2.5 \\
\hline 7215 & Riggers and Cable Splicers & Level 1.5 & Level 3 \\
\hline 7221 & $\begin{array}{l}\text { Blacksmiths, Hammersmiths and Forging Press } \\
\text { Workers }\end{array}$ & Level 1.5 & Level 2 \\
\hline
\end{tabular}




\begin{tabular}{|c|c|c|c|}
\hline 7222 & Toolmakers and Related Workers & Level 2 & Level 3 \\
\hline 7223 & $\begin{array}{l}\text { Metal Working Machine Tool Setters and } \\
\text { Operators }\end{array}$ & Level 2 & Level 3 \\
\hline 7224 & $\begin{array}{l}\text { Metal Polishers, Wheel Grinders and Tool } \\
\text { Sharpeners }\end{array}$ & Level 2 & Level 2 \\
\hline 7231 & Motor Vehicle Mechanics and Repairers & Level 2 & Level 3 \\
\hline 7232 & Aircraft Engine Mechanics and Repairers & Level 2.5 & Level 3 \\
\hline 7233 & $\begin{array}{l}\text { Agricultural and Industrial Machinery } \\
\text { Mechanics and Repairers }\end{array}$ & Level 2 & Level 3 \\
\hline 7234 & Bicycle and Related Repairers & Level 2 & Level 2 \\
\hline 7311 & Precision-instrument Makers and Repairers & Level 2 & Level 3 \\
\hline 7312 & Musical Instrument Makers and Tuners & Level 2 & Level 2.5 \\
\hline 7313 & Jewellery and Precious metal Workers & Level 2 & Level 2.5 \\
\hline 7314 & Potters and Related Workers & Level 2 & Level 2 \\
\hline 7315 & Glass Makers, Cutters, Grinders and Finishers & Level 2 & Level 2 \\
\hline 7316 & $\begin{array}{l}\text { Signwriters, Decorative Painters, Engravers } \\
\text { and Etchers }\end{array}$ & Level 2 & Level 2 \\
\hline 7317 & $\begin{array}{l}\text { Handicraft Workers in Wood, Basketry and } \\
\text { Related Materials }\end{array}$ & Level 1.5 & Level 2 \\
\hline 7318 & $\begin{array}{l}\text { Handicraft Workers in Textile, Leather and } \\
\text { Related Materials }\end{array}$ & Level 1.5 & Level 2 \\
\hline 7319 & Handicraft Workers Not Elsewhere Classified & Level 2 & Level 2.5 \\
\hline 7321 & Pre-press Technicians & Level 2 & Level 2.5 \\
\hline 7322 & Printers & Level 2 & Level 2.5 \\
\hline 7323 & Print Finishing and Binding Workers & Level 1.5 & Level 2 \\
\hline 7411 & Building and Related Electricians & Level 3 & Level 3.5 \\
\hline 7412 & Electrical Mechanics and Fitters & Level 2.5 & Level 3.5 \\
\hline 7413 & Electrical Line Installers and Repairers & Level 2 & Level 3.5 \\
\hline 7421 & Electronics Mechanics and Servicers & Level 2.5 & Level 3.5 \\
\hline 7422 & $\begin{array}{l}\text { Information and Communications Technology } \\
\text { Installers and Servicers }\end{array}$ & Level 3 & Level 3.5 \\
\hline 7511 & $\begin{array}{l}\text { Butchers, Fishmongers and Related Food } \\
\text { Preparers }\end{array}$ & Level 1 & Level 2 \\
\hline 7512 & $\begin{array}{l}\text { Bakers, Pastry-cooks and Confectionery } \\
\text { Makers }\end{array}$ & Level 1.5 & Level 2.5 \\
\hline 7513 & Dairy Products Makers & Level 1.5 & Level 2.5 \\
\hline 7514 & Fruit, Vegetable and Related Preservers & Level 1 & Level 2 \\
\hline
\end{tabular}




\begin{tabular}{|c|c|c|c|}
\hline 7515 & Food and Beverage Tasters and Graders & Level 2 & Level 2.5 \\
\hline \multirow[t]{2}{*}{7516} & Tobacco Preparers and Tobacco Products & Level 1 & Level 2 \\
\hline & Makers & & \\
\hline 7521 & Wood Treaters & Level 2 & Level 2 \\
\hline 7522 & Cabinet-makers and Related Workers & Level 2 & Level 3 \\
\hline \multirow[t]{2}{*}{7523} & Woodworking Machine Tool Setters and & Level 2 & Level 2 \\
\hline & Operators & & \\
\hline 7531 & Tailors, Dressmakers, Furriers and Hatters & Level 2 & Level 2.5 \\
\hline \multirow[t]{2}{*}{7532} & Garment and Related Patternmakers and & Level 2 & Level 2.5 \\
\hline & Cutters & & \\
\hline 7533 & Sewing, Embroidery and Related Workers & Level 1 & Level 1.5 \\
\hline 7534 & Upholsterers and Related Workers & Level 1.5 & Level 2 \\
\hline 7535 & Pelt Dressers, Tanners and Fellmongers & Level 1 & Level 2 \\
\hline 7536 & Shoemakers and Related Workers & Level 2 & Level 2.5 \\
\hline 7541 & Underwater Divers & Level $1+2$ & Level $2+3$ \\
\hline 7542 & Shotfirers and Blasters & Level 2.5 & Level 3 \\
\hline \multirow[t]{2}{*}{7543} & Product Graders and Testers (excluding Foods & Level 2.5 & Level 3 \\
\hline & & & \\
\hline \multirow[t]{2}{*}{7544} & Fumigators and Other Pest and Weed & Level 1 & Level 2 \\
\hline & Controllers & & \\
\hline \multirow[t]{2}{*}{7549} & Craft and Related Workers Not Elsewhere & Level 2 & Level 2 \\
\hline & Classified & & \\
\hline 8111 & Miners and Quarriers & Level 1.5 & Level 2 \\
\hline 8112 & Mineral and Stone Processing Plant Operators & Level 2 & Level 2 \\
\hline 8113 & Well Drillers and Borers and Related Workers & Level 2 & Level 2 \\
\hline \multirow[t]{2}{*}{8114} & Cement, Stone and Other Mineral Products & Level 2 & Level 2 \\
\hline & Machine Operators & & \\
\hline 8121 & Metal Processing Plant Operators & Level 2 & Level 2 \\
\hline \multirow[t]{2}{*}{8122} & Metal Finishing, Plating and Coating Machine & Level 2 & Level 2 \\
\hline & Operators & & \\
\hline \multirow[t]{2}{*}{8131} & Chemical Products Plant and Machine & Level 2 & Level 2 \\
\hline & Operators & & \\
\hline 8132 & Photographic Products Machine Operators & Level 2 & Level 2 \\
\hline
\end{tabular}




\begin{tabular}{|c|c|c|c|}
\hline 8141 & Rubber Products Machine Operators & Level 2 & Level 2 \\
\hline 8142 & Plastic Products Machine Operators & Level 2 & Level 2 \\
\hline 8143 & Paper Products Machine Operators & Level 2 & Level 2 \\
\hline 8151 & $\begin{array}{l}\text { Fibre Preparing, Spinning and Winding } \\
\text { Machine Operators }\end{array}$ & Level 2 & Level 2 \\
\hline 8152 & Weaving and Knitting Machine Operators & Level 2 & Level 2 \\
\hline 8153 & Sewing Machine Operators & Level 2 & Level 2 \\
\hline 8154 & $\begin{array}{l}\text { Bleaching, Dyeing and Fabric Cleaning } \\
\text { Machine Operators }\end{array}$ & Level 2 & Level 2 \\
\hline 8155 & Fur and Leather Preparing Machine Operators & Level 2 & Level 2 \\
\hline 8156 & Shoemaking and Related Machine Operators & Level 2 & Level 2 \\
\hline 8157 & Laundry Machine Operators & Level 1.5 & Level 2 \\
\hline 8159 & $\begin{array}{l}\text { Textile, Fur and Leather Products Machine } \\
\text { Operators Not Elsewhere Classified }\end{array}$ & Level 2 & Level 2 \\
\hline 8160 & Food and Related Products Machine Operators & Level 2 & Level 2 \\
\hline 8171 & Pulp and Papermaking Plant Operators & Level 2 & Level 2 \\
\hline 8172 & Wood Processing Plant Operators & Level 2 & Level 2 \\
\hline 8181 & Glass and Ceramics Plant Operators & Level 2 & Level 2 \\
\hline 8182 & Steam Engine and Boiler Operators & Level 2 & Level 2 \\
\hline 8183 & $\begin{array}{l}\text { Packing, Bottling and Labelling Machine } \\
\text { Operators }\end{array}$ & Level 1.5 & Level 2 \\
\hline 8189 & $\begin{array}{l}\text { Stationary Plant and Machine Operators Not } \\
\text { Elsewhere Classified }\end{array}$ & Level 2 & Level 2 \\
\hline 8211 & Mechanical Machinery Assemblers & Level 2 & Level 2 \\
\hline 8212 & $\begin{array}{l}\text { Electrical and Electronic Equipment } \\
\text { Assemblers }\end{array}$ & Level 2 & Level 2 \\
\hline 8219 & Assemblers Not Elsewhere Classified & Level 2 & Level 2 \\
\hline 8311 & Locomotive Engine Drivers & Level 1.5 & Level 2 \\
\hline 8312 & Railway Brake, Signal and Switch Operators & Level 2 & Level 2 \\
\hline 8321 & Motorcycle Drivers & Level 1 & Level 1 \\
\hline 8322 & Car, Taxi and Van Drivers & Level 1 & Level 1 \\
\hline 8331 & Bus and Tram Drivers & Level 1 & Level 1 \\
\hline
\end{tabular}




\begin{tabular}{|c|c|c|c|}
\hline 8332 & Heavy Truck and Lorry Drivers & Level 1 & Level 2 \\
\hline 8341 & Mobile Farm and Forestry Plant Operators & Level 1 & Level 1.5 \\
\hline 8342 & Earthmoving and Related Plant Operators & Level 1 & Level 1.5 \\
\hline 8343 & Crane, Hoist and Related Plant Operators & Level 1 & Level 2 \\
\hline 8344 & Lifting Truck Operators & Level 1 & Level 1.5 \\
\hline 8350 & Ships' Deck Crews and Related Workers & Level 1 & Level 1 \\
\hline 9111 & Domestic Cleaners and Helpers & Level 0 & Level 0 \\
\hline 9112 & $\begin{array}{l}\text { Cleaners and Helpers in Offices, Hotels and } \\
\text { other Establishments }\end{array}$ & Level 0 & Level 0 \\
\hline 9121 & Hand Launderers and Pressers & Level 0 & Level 0 \\
\hline 9122 & Vehicle Cleaners & Level 0 & Level 0 \\
\hline 9123 & Window Cleaners & Level 0 & Level 0 \\
\hline 9129 & Other Cleaning Workers & Level 0 & Level 0 \\
\hline 9211 & Crop Farm Labourers & Level 0 & Level 0 \\
\hline 9212 & Livestock Farm Labourers & Level 0 & Level 0 \\
\hline 9213 & Mixed Crop and Livestock Farm Labourers & Level 0 & Level 0 \\
\hline 9214 & Garden and Horticultural Labourers & Level 0 & Level 0 \\
\hline 9215 & Forestry Labourers & Level 0 & Level 0 \\
\hline 9216 & Fishery and Aquaculture Labourers & Level 0 & Level 0 \\
\hline 9311 & Mining and Quarrying Labourers & Level 0 & Level 0 \\
\hline 9312 & Civil Engineering Labourers & Level 0 & Level 0 \\
\hline 9313 & Building Construction Labourers & Level 0 & Level 0 \\
\hline 9321 & Hand Packers & Level 0 & Level 0 \\
\hline 9329 & $\begin{array}{l}\text { Manufacturing Labourers Not Elsewhere } \\
\text { Classified }\end{array}$ & Level 0 & Level 0 \\
\hline 9331 & Hand and Pedal Vehicle Drivers & Level 0 & Level 0 \\
\hline 9332 & $\begin{array}{l}\text { Drivers of Animal-drawn Vehicles and } \\
\text { Machinery }\end{array}$ & Level 0 & Level 0 \\
\hline 9333 & Freight Handlers & Level 0 & Level 0 \\
\hline 9334 & Shelf fillers & Level 0 & Level 0 \\
\hline 9411 & Fast Food Preparers & Level 0 & Level 0 \\
\hline 9412 & Kitchen Helpers & Level 0 & Level 0 \\
\hline
\end{tabular}




\begin{tabular}{|c|c|c|c|}
\hline 9510 & Street and Related Services Workers & Level 0 & Level 0 \\
\hline 9520 & Street Vendors (excluding Food) & Level 0 & Level 1 \\
\hline 9611 & Garbage and Recycling Collectors & Level 0 & Level 0 \\
\hline 9612 & Refuse Sorters & Level 0 & Level 0 \\
\hline 9613 & Sweepers and Related Labourers & Level 0 & Level 0 \\
\hline 9621 & $\begin{array}{l}\text { Messengers, Package Deliverers and Luggage } \\
\text { Porters }\end{array}$ & Level 0 & Level 0 \\
\hline 9622 & Odd-job Persons & Level 0 & Level 0 \\
\hline 9623 & $\begin{array}{l}\text { Meter Readers and Vending-machine } \\
\text { Collectors }\end{array}$ & Level 1 & Level 1 \\
\hline 9624 & Water and Firewood Collectors & Level 0 & Level 0 \\
\hline 9629 & Elementary Workers Not Elsewhere Classified & Level 0 & Level 0 \\
\hline
\end{tabular}




\section{References}

Adalet McGowan, M., \& Andrews, D. (2017). Skills mismatch, productivity and policies. OECD Economics Department Working Papers, 1403.

American Educational Research Association, American Psychological Association, \& National Council on Measurement in Education. (2014). Standards for educational and psychological testing, 2014 edition: American Educational Research Association (AERA).

Béduwé, C., \& Giret, J.-F. (2011). Mismatch of vocational graduates: what penalty on French labour market. Journal of Vocational Behavior, 78(1), 68-79.

Brannick, M. T., \& Levine, E. L. (2002). Job Analysis: Methods, research and applications. Thousand Oaks: Sage Publications.

Dahlstedt, I. (2011). Occupational match: Over- and undereducation among immigrants in the Swedish labor market. Journal of International Migration and Integration / Revue de l'integration et de la migration internationale, 12(3), 349-367.

Desjardins, R., \& Rubenson, K. (2011). An analysis of skill mismatch using direct measures of skills. OECD Education Working Papers, 63.

Dierdorff, E. C., \& Wilson, M. A. (2003). A meta-analysis of Job Analysis reliability. The Journal Of Applied Psychology, 88(4), 635-646.

European Centre for the Development of Vocational Training. (2014). Terminology of european education and training policy. Luxembourg: Publications Office of the European Union

Fleisher, M. S., \& Tsacoumis, S. (2018). O*NET: Analyst occupational skills ratings: Procedures updates. In: National Centre for O*NET Development.

Global Agenda Council on Employment. (2014). Matching skills and labour market needs: Building social partnerships for better skills and better jobs. In: World Economic Forum.

Hartog, J. (2000). Over-education and earnings: Where are we, where should we go? Economics of Education Review, 19(2), 131-147.

Harvey, R. J., \& Wilson, M. A. (2000). Yes Virginia, there is an objective reality in Job Analysis. Journal of Organizational Behavior, 21(7), 829-854.

International Conference of Labour Statisticians. (2018). Guidelines concerning measurement of qualifications and skill mismatches of persons in employment. Retrieved from Geneva:

International Labour Office. (2012). International Standard Classification of Occupations 2008 (ISCO08). Structure, group definitions and correspondence tables (Vol. 1). Switzerland.

Jenkins, S. M., \& Curtin, P. (2006). Adapting Job Analysis methodology to improve evaluation practice. American Journal of Evaluation, 27(4), 485-494.

Katz-Gerro, T., \& Yaish, M. (2003). Higher education: Is more better? Gender differences in labour market returns to tertiary education in Israel. Oxford Review of Education, 29(4), 571-592.

Levels, M., Van der Velden, R., \& Allen, J. (2014). Educational mismatches and skills: New empirical tests of old hypotheses. Oxford Economic Papers, 66(4), 959-982. doi:10.1093/oep/gpu024.

Lievens, F., \& Sanchez, J. I. (2007). Can training improve the quality of inferences made by raters in competency modeling? A quasi-experiment. Journal of Applied Psychology, 92(3), 812-819.

Lievens, F., Sanchez, J. I., Bartram, D., \& Brown, A. (2010). Lack of consensus among competency ratings of the same occupation: noise or substance? The Journal Of Applied Psychology, 95(3), 562571. 
McGuinness, S., Pouliakas, K., \& Redmond, P. (2018). Skills mismatch: Concepts, measurement and policy approaches Journal of Economic Surveys, 32(4), 985-1015.

Nordin, M., Persson, I., \& Rooth, D.-O. (2010). Education-occupation mismatch: Is there an income penalty? Economics of Education Review, 29(6), 1047-1059.

O*NET. (2019). O*NET ${ }^{\circledR} 23.2$ Database. Retrieved from https://www.onetcenter.org/database.html\#individual-files

OECD. (2013). The Survey of Adult Skills: Reader's Companion. OECD Publishing

OECD. (2016). Getting skills right: Assessing and anticipating changing skill needs. Paris: OECD Publishing.

OECD. (2018). About the Survey of Adult Skills (PIAAC). Retrieved from http://www.oecd.org/skills/piaac/aboutpiaac.htm

Office for National Statistics. (2010). Standard Occupational Classification 2010. Volume 1: Structure and descriptions of unit groups. In. United Kingdom: Palgrave Macmillan.

Perry, A., Wiederhold, S., \& Ackermann-Piek, D. (2014). How can skill mismatch be measured? New approaches with PIAAC. Methods, data, analysis, 8(2), 137-174.

Surrette, M. A., Aamodt, M. G., \& Johnson, D. L. (1990). Effects of analyst training and amount of available job related information on Job Analysis ratings. Journal of Business \& Psychology, 4(4), 439-451.

Van der Velden, R., \& Bijlsma, I. (2019). Effective skill: a new theoretical perspective on the relation between skills, skill use, mismatches, and wages. Oxford Economic Papers, 71(1), 145-165.

Verhaest, D., \& Omey, E. (2006). Measuring the incidence of over- and undereducation. Quality and Quantity, 40(5), 416-436.

Wolbers, M. (2013). Job mismatches and their labour-market effects among school-leavers in Europe. European Sociological Review, 19(3), 249-266. 


\section{Appendix 1: ISCO-08 Major, Sub-major, Minor and Unit groups}

\section{Managers}

11. Chief Executives, Senior Officials and Legislators

111. Legislators and Senior Officials

1111. Legislators

1112. Senior Government Officials

1113. Traditional Chiefs and Heads of Villages

1114. Senior Officials of Special-Interest Organizations

112. Managing Directors and Chief Executives

1120. Managing Directors and Chief Executives

12. Administrative and Commercial Managers

121. Business Services and Administration Managers

1211. Finance Managers

1212. Human Resources Managers

1213. Policy and Planning Managers

1219. Business Services and Administration Managers Not Elsewhere Classified

122. Sales, Marketing and Development Managers

1221. Sales and Marketing Managers

1222. Advertising and Public Relations Managers

1223. Research and Development Managers

13. Production and Specialized Services Managers

131. Production Managers in Agriculture, Forestry and Fisheries

1311. Agricultural and Forestry Production Managers

1312. Aquaculture and Fisheries Production Managers

132. Manufacturing, Mining, Construction and Distribution Managers

1321. Manufacturing Managers

1322. Mining Managers

1323. Construction Managers

1324. Supply, Distribution and Related Managers

133. Information and Communications Technology Services Managers

1330. Information and Communications Technology Services Managers

134. Professional Services Managers

1341. Child Care Services Managers

1342. Health Services Managers

1343. Aged Care Services Managers

1344. Social Welfare Managers

1345. Education Managers

1346. Financial and Insurance Services Branch Managers

1349. Professional Services Managers Not Elsewhere Classified

14. Hospitality, Retail and Other Services Managers

141. Hotel and Restaurant Managers

1411. Hotel Managers

1412. Restaurant Managers 
142. Retail and Wholesale Trade Managers

1420. Retail and Wholesale Trade Managers

143. Other Services Managers

1431. Sports, Recreation and Cultural Centre Managers

1439. Services Managers Not Elsewhere Classified

\section{Professionals}

21. Science and Engineering Professionals

211. Physical and Earth Science Professionals

2111. Physicists and Astronomers

2112. Meteorologists

2113. Chemists

2114. Geologists and Geophysicists

212. Mathematicians, Actuaries and Statisticians

2120. Mathematicians, Actuaries and Statisticians

213. Life Science Professionals

2131. Biologists, Botanists, Zoologists and Related Professionals

2132. Farming, Forestry and Fisheries Advisers

2133. Environmental Protection Professionals

214. Engineering Professionals (excluding Electrotechnology)

2141. Industrial and Production Engineers

2142. Civil Engineers

2143. Environmental Engineers

2144. Mechanical Engineers

2145. Chemical Engineers

2146. Mining Engineers, Metallurgists and Related Professionals

2149. Engineering Professionals Not Elsewhere Classified

215. Electrotechnology Engineers

2151. Electrical Engineers 2152 Electronics Engineers

2153. Telecommunications Engineers

216. Architects, Planners, Surveyors and Designers

2161. Building Architects

2162. Landscape Architects

2163. Product and Garment Designers

2164. Town and Traffic Planners

2165. Cartographers and Surveyors

2166. Graphic and Multimedia Designers

22. Health Professionals

221. Medical Doctors

2211. Generalist Medical Practitioners

2212. Specialist Medical Practitioners

222. Nursing and Midwifery Professionals

2221. Nursing Professionals

2222. Midwifery Professionals

223. Traditional and Complementary Medicine Professionals 
2230. Traditional and Complementary Medicine Professionals

224. Paramedical Practitioners

2240. Paramedical Practitioners

225. Veterinarians

2250. Veterinarians

226. Other Health Professionals

2261. Dentists

2262. Pharmacists

2263. Environmental and Occupational Health and Hygiene Professionals

2264. Physiotherapists

2265. Dieticians and Nutritionists

2266. Audiologists and Speech Therapists

2267. Optometrists and Ophthalmic Opticians

2269. Health Professionals Not Elsewhere Classified

23. Teaching Professionals

231. University and Higher Education Teachers

2310. University and Higher Education Teachers

232. Vocational Education Teachers

2320. Vocational Education Teachers

233. Secondary Education Teachers

2330. Secondary Education Teachers

234. Primary School and Early Childhood Teachers

2341. Primary School Teachers

2342. Early Childhood Educators

235. Other Teaching Professionals

2351. Education Methods Specialists

2352. Special Needs Teachers

2353. Other Language Teachers

2354. Other Music Teachers

2355. Other Arts Teachers

2356. Information Technology Trainers

2359. Teaching Professionals Not Elsewhere Classified

24. Business and Administration Professionals

241. Finance Professionals

2411. Accountants

2412. Financial and Investment Advisers

2413. Financial Analysts

242. Administration Professionals

2421. Management and Organization Analysts

2422. Policy Administration Professionals

2423. Personnel and Careers Professionals

2424. Training and Staff Development Professionals

243. Sales, Marketing and Public Relations Professionals

2431. Advertising and Marketing Professionals

2432. Public Relations Professionals 
2433. Technical and Medical Sales Professionals (excluding ICT)

2434. Information and Communications Technology Sales Professionals

25. Information and Communications Technology Professionals

251. Software and Applications Developers and Analysts

2511. Systems Analysts

2512. Software Developers

2513. Web and Multimedia Developers

2514. Applications Programmers

2519. Software and Applications Developers and Analysts Not Elsewhere Classified

252. Database and Network Professionals

2521. Database Designers and Administrators

2522. Systems Administrators

2523. Computer Network Professionals

2529. Database and Network Professionals Not Elsewhere Classified

26. Legal, Social and Cultural Professionals

261. Legal Professionals

2611. Lawyers

2612. Judges

2619. Legal Professionals Not Elsewhere Classified

262. Librarians, Archivists and Curators

2621. Archivists and Curators

2622. Librarians and Related Information Professionals

263. Social and Religious Professionals

2631. Economists

2632. Sociologists, Anthropologists and Related Professionals

2633. Philosophers, Historians and Political Scientists

2634. Psychologists

2635. Social Work and Counselling Professionals

2636. Religious Professionals

264. Authors, Journalists and Linguists

2641. Authors and Related Writers

2642. Journalists

2643. Translators, Interpreters and Other Linguists

265. Creative and Performing Artists

2651. Visual Artists

2652. Musicians, Singers and Composers

2653. Dancers and Choreographers

2654. Film, Stage and Related Directors and Producers

2655. Actors

2656. Announcers on Radio, Television and Other Media

2659. Creative and Performing Artists Not Elsewhere Classified

\section{Technicians and Associate Professionals}

31. Science and Engineering Associate Professionals 
311. Physical and Engineering Science Technicians

3111. Chemical and Physical Science Technicians

3112. Civil Engineering Technicians

3113. Electrical Engineering Technicians

3114. Electronics Engineering Technicians

3115. Mechanical Engineering Technicians

3116. Chemical Engineering Technicians

3117. Mining and Metallurgical Technicians

3118. Draughtspersons

3119. Physical and Engineering Science Technicians Not Elsewhere Classified

312. Mining, Manufacturing and Construction Supervisors

3121. Mining Supervisors

3122. Manufacturing Supervisors

3123. Construction Supervisors

313. Process Control Technicians

3131. Power Production Plant Operators

3132. Incinerator and Water Treatment Plant Operators

3133. Chemical Processing Plant Controllers

3134. Petroleum and Natural Gas Refining Plant Operators

3135. Metal Production Process Controllers

3139. Process Control Technicians Not Elsewhere Classified

314. Life Science Technicians and Related Associate Professionals

3141. Life Science Technicians (excluding Medical)

3142. Agricultural Technicians

3143. Forestry Technicians

315. Ship and Aircraft Controllers and Technicians

3151. Ships' Engineers

3152. Ships' Deck Officers and Pilots

3153. Aircraft Pilots and Related Associate Professionals

3154. Air Traffic Controllers

3155. Air Traffic Safety Electronics Technicians

32. Health Associate Professionals

321. Medical and Pharmaceutical Technicians

3211. Medical Imaging and Therapeutic Equipment Technicians

3212. Medical and Pathology Laboratory Technicians

3213. Pharmaceutical Technicians and Assistants

3214. Medical and Dental Prosthetic Technicians

322. Nursing and Midwifery Associate Professionals

3221. Nursing Associate Professionals

3222. Midwifery Associate Professionals

323. Traditional and Complementary Medicine Associate Professionals

3230. Traditional and Complementary Medicine Associate Professionals

324. Veterinary Technicians and Assistants

3240. Veterinary Technicians and Assistants

325. Other Health Associate Professionals 
3251. Dental Assistants and Therapists

3252. Medical Records and Health Information Technicians

3253. Community Health Workers

3254. Dispensing Opticians

3255. Physiotherapy Technicians and Assistants

3256. Medical Assistants

3257. Environmental and Occupational Health Inspectors and Associates

3258. Ambulance Workers

3259. Health Associate Professionals Not Elsewhere Classified

33. Business and Administration Associate Professionals

331. Financial and Mathematical Associate Professionals

3311. Securities and Finance Dealers and Brokers

3312. Credit and Loans Officers

3313. Accounting Associate Professionals

3314. Statistical, Mathematical and Related Associated Professionals 3315.

Valuers and Loss Assessors

332. Sales and Purchasing Agents and Brokers

3321. Insurance Representatives

3322. Commercial Sales Representatives

3323. Buyers

3324. Trade Brokers

333. Business Service Agents

3331. Clearing and Forwarding Agents

3332. Conference and Event Planners

3333. Employment Agents and Contractors

3334. Real Estate Agents and Property Managers

3339. Business Services Agents Not Elsewhere Classified

334. Administrative and Specialized Secretaries

3341. Office Supervisors

3342. Legal Secretaries

3343. Administrative and Executive Secretaries

3344. Medical Secretaries

335. Government Regulatory Associate Professionals

3351. Customs and Border Inspectors

3352. Government Tax and Excise Officials

3353. Government Social Benefits Officials

3354. Government Licensing Officials

3355. Police Inspectors and Detectives

3359. Government Regulatory Associate Professionals Not Elsewhere Classified

34. Legal, Social, Cultural and Related Associate Professionals

341. Legal, Social and Religious Associate Professionals

3411. Legal and Related Associate Professionals

3412. Social Work Associate Professionals

3413. Religious Associate Professionals 
342. Sports and Fitness Workers

3421. Athletes and Sports Players

3422. Sports Coaches, Instructors and Officials

3423. Fitness and Recreation Instructors and Programme Leaders

343. Artistic, Cultural and Culinary Associate Professionals

3431. Photographers

3432. Interior Designers and Decorators

3433. Gallery, Museum and Library Technicians

3434. Chefs

3435. Other Artistic and Cultural Associate Professionals

35. Information and Communications Technicians

351. Information and Communications Technology Operations and User Support Technicians

3511. Information and Communications Technology Operations Technicians

3512. Information and Communications Technology User Support Technicians

3513. Computer Network and Systems Technicians

3514. Web Technicians

352. Telecommunications and Broadcasting Technicians

3521. Broadcasting and Audiovisual Technicians

3522. Telecommunications Engineering Technicians

\section{Clerical Support Workers}

41. General and Keyboard Clerks

411. General Office Clerks

4110. General Office Clerks

412. Secretaries (general)

4120. Secretaries (general)

413. Keyboard Operators

4131. Typists and Word Processing Operators

4132. Data Entry Clerks

42. Customer Services Clerks

421. Tellers, Money Collectors and Related Clerks

4211. Bank Tellers and Related Clerks

4212. Bookmakers, Croupiers and Related Gaming Workers

4213. Pawnbrokers and Money-lenders

4214. Debt Collectors and Related Workers

422. Client Information Workers

4221. Travel Consultants and Clerks

4222. Contact Centre Information Clerks

4223. Telephone Switchboard Operators

4224. Hotel Receptionists

4225. Inquiry Clerks

4226. Receptionists (general)

4227. Survey and Market Research Interviewers

4229. Client Information Workers Not Elsewhere Classified 
43. Numerical and Material Recording Clerks

431. Numerical Clerks

4311. Accounting and Bookkeeping Clerks

4312. Statistical, Finance and Insurance Clerks

4313. Payroll Clerks

432. Material Recording and Transport Clerks

4321. Stock Clerks

4322. Production Clerks

4323. Transport Clerks

44. Other Clerical Support Workers

441. Other Clerical Support Workers

4411. Library Clerks

4412. Mail Carriers and Sorting Clerks

4413. Coding, Proofreading and Related Clerks

4414. Scribes and Related Workers

4415. Filing and Copying Clerks

4416. Personnel Clerks

4419. Clerical Support Workers Not Elsewhere Classified

\section{Services and Sales Workers}

51. Personal Services Workers

511. Travel Attendants, Conductors and Guides

5111. Travel Attendants and Travel Stewards

5112. Transport Conductors

5113. Travel Guides

512. Cooks

5120. Cooks

513. Waiters and Bartenders

5131. Waiters

5132. Bartenders

514. Hairdressers, Beauticians and Related Workers

5141. Hairdressers

5142. Beauticians and Related Workers

515. Building and Housekeeping Supervisors

5151. Cleaning and Housekeeping Supervisors in Offices, Hotels and Other

Establishments

5152. Domestic Housekeepers

5153. Building Caretakers

516. Other Personal Services Workers

5161. Astrologers, Fortune-tellers and Related Workers

5162. Companions and Valets

5163. Undertakers and Embalmers

5164. Pet Groomers and Animal Care Workers

5165. Driving Instructors

5169. Personal Services Workers Not Elsewhere Classified 
52. Sales Workers

521. Street and Market Salespersons

5211. Stall and Market Salespersons

5212. Street Food Salespersons

522. Shop Salespersons

5221. Shopkeepers

5222. Shop Supervisors

5223. Shop Sales Assistants

523. Cashiers and Ticket Clerks

5230. Cashiers and Ticket Clerks

524. Other Sales Workers

5241. Fashion and Other Models

5242. Sales Demonstrators

5243. Door-to-door Salespersons

5244. Contact Centre Salespersons

5245. Service Station Attendants

5246. Food Service Counter Attendants

5249. Sales Workers Not Elsewhere Classified

53. Personal Care Workers

531. Child Care Workers and Teachers' Aides

5311. Child Care Workers

5312. Teachers' Aides

532. Personal Care Workers in Health Services

5321. Health Care Assistants

5322. Home-based Personal Care Workers

5329. Personal Care Workers Not Elsewhere Classified

54. Protective Services Workers

541. Protective Services Workers

5411. Firefighters

5412. Police Officers

5413. Prison Guards

5414. Security Guards

5419. Protective Services Workers Not Elsewhere Classified

\section{Skilled Agricultural, Forestry and Fishery Workers}

61. Market-oriented Skilled Agricultural Workers

611. Market Gardeners and Crop Growers

6111. Field Crop and Vegetable Growers

6112. Tree and Shrub Crop Growers

6113. Gardeners; Horticultural and Nursery Growers

6114. Mixed Crop Growers

612. Animal Producers

6121. Livestock and Dairy Producers

6122. Poultry Producers

6123. Apiarists and Sericulturists 
6129. Animal Producers Not Elsewhere Classified

613. Mixed Crop and Animal Producers

6130. Mixed Crop and Animal Producers

62. Market-oriented Skilled Forestry, Fishery and Hunting Workers

621. Forestry and Related Workers

6210. Forestry and Related Workers

622. Fishery Workers, Hunters and Trappers

6221. Aquaculture Workers

6222. Inland and Coastal Waters Fishery Workers

6223. Deep-sea Fishery Workers

6224. Hunters and Trappers

63. Subsistence Farmers, Fishers, Hunters and Gatherers

631. Subsistence Crop Farmers

6310. Subsistence Crop Farmers

632. Subsistence Livestock Farmers

6320. Subsistence Livestock Farmers

633. Subsistence Mixed Crop and Livestock Farmers

6330. Subsistence Mixed Crop and Livestock Farmers

634. Subsistence Fishers, Hunters, Trappers and Gatherers

6340. Subsistence Fishers, Hunters, Trappers and Gatherers

\section{Craft and related Trades Workers}

71. Building and Related Trades Workers (excluding Electricians)

711. Building Frame and Related Trades Workers

7111. House Builders

7112. Bricklayers and Related Workers

7113. Stonemasons, Stone Cutters, Splitters and Carvers

7114. Concrete Placers, Concrete Finishers and Related Workers 7115.

Carpenters and Joiners

7119. Building Frame and Related Trades Workers Not Elsewhere Classified

712. Building Finishers and Related Trades Workers

7121. Roofers

7122. Floor Layers and Tile Setters

7123. Plasterers

7124. Insulation Workers

7125. Glaziers

7126. Plumbers and Pipe Fitters

7127. Air Conditioning and Refrigeration Mechanics

713. Painters, Building Structure Cleaners and Related Trades Workers

7131. Painters and Related Workers

7132. Spray Painters and Varnishers

7133. Building Structure Cleaners

72. Metal, Machinery and Related Trades Workers

721. Sheet and Structural Metal Workers, Moulders and Welders, and Related Workers

7211. Metal Moulders and Coremakers 
7212. Welders and Flame Cutters

7213. Sheet Metal Workers

7214. Structural Metal Preparers and Erectors

7215. Riggers and Cable Splicers

722. Blacksmiths, Toolmakers and Related Trades Workers

7221. Blacksmiths, Hammersmiths and Forging Press Workers

7222. Toolmakers and Related Workers

7223. Metal Working Machine Tool Setters and Operators

7224. Metal Polishers, Wheel Grinders and Tool Sharpeners

723. Machinery Mechanics and Repairers

7231. Motor Vehicle Mechanics and Repairers

7232. Aircraft Engine Mechanics and Repairers

7233. Agricultural and Industrial Machinery Mechanics and Repairers 7234.

Bicycle and Related Repairers

73. Handicraft and Printing Workers

731. Handicraft Workers

7311. Precision-instrument Makers and Repairers

7312. Musical Instrument Makers and Tuners

7313. Jewellery and Precious Metal Workers

7314. Potters and Related Workers

7315. Glass Makers, Cutters, Grinders and Finishers

7316. Signwriters, Decorative Painters, Engravers and Etchers

7317. Handicraft Workers in Wood, Basketry and Related Materials 7318.

Handicraft Workers in Textile, Leather and Related Materials 7319. Handicraft

Workers Not Elsewhere Classified

732. Printing Trades Workers

7321. Pre-press Technicians

7322. Printers

7323. Print Finishing and Binding Workers

74. Electrical and Electronic Trades Workers

741. Electrical Equipment Installers and Repairers

7411. Building and Related Electricians

7412. Electrical Mechanics and Fitters

7413. Electrical Line Installers and Repairers

742. Electronics and Telecommunications Installers and Repairers

7421. Electronics Mechanics and Servicers

7422. Information and Communications Technology Installers and Servicers

75. Food Processing, Woodworking, Garment and Other Craft and Related Trades Workers

751. Food Processing and Related Trade Workers

7511. Butchers, Fishmongers and Related Food Preparers

7512. Bakers, Pastry-cooks and Confectionery Makers

7513. Dairy Products Makers

7514. Fruit, Vegetable and Related Preservers

7515. Food and Beverage Tasters and Graders

7516. Tobacco Preparers and Tobacco Products Makers 
752. Wood Treaters, Cabinet-makers and Related Trades Workers

7521. Wood Treaters

7522. Cabinet-makers and Related Workers

7523. Woodworking Machine Tool Setters and Operators

753. Garment and Related Trades Workers

7531. Tailors, Dressmakers, Furriers and Hatters

7532. Garment and Related Patternmakers and Cutters

7533. Sewing, Embroidery and Related Workers

7534. Upholsterers and Related Workers

7535. Pelt Dressers, Tanners and Fellmongers

7536. Shoemakers and Related Workers

754. Other Craft and Related Workers

7541. Underwater Divers

7542. Shotfirers and Blasters

7543. Product Graders and Testers (excluding Foods and Beverages) 7544.

Fumigators and Other Pest and Weed Controllers

7549. Craft and Related Workers Not Elsewhere Classified

\section{Plant and Machine Operators and Assemblers}

81. Stationary Plant and Machine Operators

811. Mining and Mineral Processing Plant Operators

8111. Miners and Quarriers

8112. Mineral and Stone Processing Plant Operators

8113. Well Drillers and Borers and Related Workers

8114. Cement, Stone and Other Mineral Products Machine Operators

812. Metal Processing and Finishing Plant Operators

8121. Metal Processing Plant Operators

8122. Metal Finishing, Plating and Coating Machine Operators

813. Chemical and Photographic Products Plant and Machine Operators

8131. Chemical Products Plant and Machine Operators

8132. Photographic Products Machine Operators

814. Rubber, Plastic and Paper Products Machine Operators

8141. Rubber Products Machine Operators

8142. Plastic Products Machine Operators

8143. Paper Products Machine Operators

815. Textile, Fur and Leather Products Machine Operators

8151. Fibre Preparing, Spinning and Winding Machine Operators

8152. Weaving and Knitting Machine Operators

8153. Sewing Machine Operators

8154. Bleaching, Dyeing and Fabric Cleaning Machine Operators

8155. Fur and Leather Preparing Machine Operators

8156. Shoemaking and Related Machine Operators

8157. Laundry Machine Operators

8159. Textile, Fur and Leather Products Machine Operators Not Elsewhere

Classified 
816. Food and Related Products Machine Operators

8160. Food and Related Products Machine Operators

817. Wood Processing and Papermaking Plant Operators

8171. Pulp and Papermaking Plant Operators

8172. Wood Processing Plant Operators

818. Other Stationary Plant and Machine Operators

8181. Glass and Ceramics Plant Operators

8182. Steam Engine and Boiler Operators

8183. Packing, Bottling and Labelling Machine Operators

8189. Stationary Plant and Machine Operators Not Elsewhere Classified

82. Assemblers

821. Assemblers

8211. Mechanical Machinery Assemblers

8212. Electrical and Electronic Equipment Assemblers

8219. Assemblers Not Elsewhere Classified

83. Drivers and Mobile Plant Operators

831. Locomotive Engine Drivers and Related Workers

8311. Locomotive Engine Drivers

8312. Railway Brake, Signal and Switch Operators

832. Car, Van and Motorcycle Drivers

8321. Motorcycle Drivers

8322. Car, Taxi and Van Drivers

833. Heavy Truck and Bus Drivers

8331. Bus and Tram Drivers

8332. Heavy Truck and Lorry Drivers

834. Mobile Plant Operators

8341. Mobile Farm and Forestry Plant Operators

8342. Earthmoving and Related Plant Operators

8343. Crane, Hoist and Related Plant Operators

8344. Lifting Truck Operators

835. Ships' Deck Crews and Related Workers

8350. Ships' Deck Crews and Related Workers

\section{Elementary Occupations}

91. Cleaners and Helpers

911. Domestic, Hotel and Office Cleaners and Helpers

9111. Domestic Cleaners and Helpers

9112. Cleaners and Helpers in Offices, Hotels and Other Establishments

912. Vehicle, Window, Laundry and Other Hand Cleaning Workers

9121. Hand Launderers and Pressers

9122. Vehicle Cleaners

9123. Window Cleaners

9129. Other Cleaning Workers

92. Agricultural, Forestry and Fishery Labourers

921. Agricultural, Forestry and Fishery Labourers 
9211. Crop Farm Labourers

9212. Livestock Farm Labourers

9213. Mixed Crop and Livestock Farm Labourers

9214. Garden and Horticultural Labourers

9215. Forestry Labourers

9216. Fishery and Aquaculture Labourers

93. Labourers in Mining, Construction, Manufacturing and Transport

931. Mining and Construction Labourers

9311. Mining and Quarrying Labourers

9312. Civil Engineering Labourers

9313. Building Construction Labourers

932. Manufacturing Labourers

9321. Hand Packers

9329. Manufacturing Labourers Not Elsewhere Classified

933. Transport and Storage Labourers

9331. Hand and Pedal Vehicle Drivers

9332. Drivers of Animal-drawn Vehicles and Machinery

9333. Freight Handlers

9334. Shelf Fillers

94. Food Preparation Assistants

941. Food Preparation Assistants

9411. Fast Food Preparers

9412. Kitchen Helpers

95. Street and Related Sales and Services Workers

951. Street and Related Services Workers

9510. Street and Related Services Workers

952. Street Vendors (excluding Food)

9520. Street Vendors (excluding Food)

96. Refuse Workers and Other Elementary Workers

961. Refuse Workers

9611. Garbage and Recycling Collectors

9612. Refuse Sorters

9613. Sweepers and Related Labourers

962. Other Elementary Workers

9621. Messengers, Package Deliverers and Luggage Porters

9622. Odd-job Persons

9623. Meter Readers and Vending-machine Collectors

9624. Water and Firewood Collectors

9629. Elementary Workers Not Elsewhere Classified

\section{Armed Forces Occupations}

01. Commissioned Armed Forces Officers

011. Commissioned Armed Forces Officers

0110. Commissioned Armed Forces Officers

02. Non-commissioned Armed Forces Officers 
021. Non-commissioned Armed Forces Officers

0210. Non-commissioned Armed Forces Officers

03. Armed Forces Occupations, Other Ranks

031. Armed Forces Occupations, Other Ranks

0310. Armed Forces Occupations, Other Ranks

Note. Reprinted from International Standard Classification of Occupations 2008 (ISCO-08), Vol. 1 (pp. 72-83) by International Labour Office, 2012. Switzerland. 


\section{Appendix 2: PIAAC Proficiency levels: literacy and numeracy}

The following table shows the different proficiency levels for literacy and numeracy from PIAAC (OECD, 2013). They range from 1 to 5 , including an extra category accounting for individuals whose proficiency level is below level 1. Participants are classified into each level based on their score on the tests, as shown in the table. An explanation of the tasks related to each level is also provided.

\begin{tabular}{|c|c|c|c|}
\hline Level & $\begin{array}{l}\text { Score } \\
\text { range }\end{array}$ & Literacy & Numeracy \\
\hline $\begin{array}{l}\text { Below } \\
1\end{array}$ & $\begin{array}{l}\text { Below } \\
176\end{array}$ & $\begin{array}{l}\text { The tasks at this level require the } \\
\text { respondent to read brief texts on familiar } \\
\text { topics to locate a single piece of specific } \\
\text { information. There is seldom any } \\
\text { competing information in the text and the } \\
\text { requested information is identical in form } \\
\text { to information in the question or } \\
\text { directive. The respondent may be } \\
\text { required to locate information in short } \\
\text { continuous texts. However, in this case, } \\
\text { the information can be located as if the } \\
\text { text was non-continuous in format. Only } \\
\text { basic vocabulary knowledge is required, } \\
\text { and the reader is not required to } \\
\text { understand the structure of sentences or } \\
\text { paragraphs or make use of other text } \\
\text { features. Tasks below Level } 1 \text { do not make } \\
\text { use of any features specific to digital texts. }\end{array}$ & $\begin{array}{l}\text { Tasks at this level require the respondents } \\
\text { to carry out simple processes such as } \\
\text { counting, sorting, performing basic } \\
\text { arithmetic operations with whole numbers } \\
\text { or money, or recognising common spatial } \\
\text { representations in concrete, familiar } \\
\text { contexts where the mathematical content } \\
\text { is explicit with little or no text or distractors. }\end{array}$ \\
\hline 1 & $\begin{array}{l}176 \text { to } \\
\text { less } \\
\text { than } \\
226 \\
\text { points }\end{array}$ & $\begin{array}{l}\text { Most of the tasks at this level require the } \\
\text { respondent to read relatively short digital } \\
\text { or print continuous, non continuous, or } \\
\text { mixed texts to locate a single piece of } \\
\text { information that is identical to or } \\
\text { synonymous with the information given in } \\
\text { the question or directive. Some tasks, } \\
\text { such as those involving non-continuous } \\
\text { texts, may require the respondent to } \\
\text { enter personal information onto a } \\
\text { document. Little, if any, competing } \\
\text { information is present. Some tasks may } \\
\text { require simple cycling through more than } \\
\text { one piece of information. Knowledge and } \\
\text { skill in recognising basic vocabulary } \\
\text { determining the meaning of sentences, } \\
\text { and reading paragraphs of text is } \\
\text { expected. }\end{array}$ & $\begin{array}{l}\text { Tasks at this level require the respondent to } \\
\text { carry out basic mathematical processes in } \\
\text { common, concrete contexts where the } \\
\text { mathematical content is explicit with little } \\
\text { text and minimal distractors. Tasks usually } \\
\text { require one-step or simple processes } \\
\text { involving counting; sorting; performing } \\
\text { basic arithmetic operations; understanding } \\
\text { simple percentages such as 50\%; and } \\
\text { locating and identifying elements of simple } \\
\text { or common graphical or spatial } \\
\text { representations. }\end{array}$ \\
\hline 2 & $\begin{array}{l}226 \text { to } \\
\text { less }\end{array}$ & $\begin{array}{l}\text { At this level, the medium of texts may be } \\
\text { digital or printed, and texts may comprise }\end{array}$ & $\begin{array}{l}\text { Tasks at this level require the respondent to } \\
\text { identify and act on mathematical }\end{array}$ \\
\hline
\end{tabular}




\begin{tabular}{|c|c|c|c|}
\hline & $\begin{array}{l}\text { than } \\
276 \\
\text { points }\end{array}$ & $\begin{array}{l}\text { continuous, non-continuous, or mixed } \\
\text { types. Tasks at this level require } \\
\text { respondents to make matches between } \\
\text { the text and information, and may require } \\
\text { paraphrasing or low-level inferences. } \\
\text { Some competing pieces of information } \\
\text { may be present. Some tasks require the } \\
\text { respondent to } \\
\text { - cycle through or integrate two or more } \\
\text { pieces of information based on criteria; } \\
\text { - compare and contrast or reason about } \\
\text { information requested in the question; or } \\
\text { - navigate within digital texts to access- } \\
\text { and-identify information from various } \\
\text { parts of a document. }\end{array}$ & $\begin{array}{l}\text { information and ideas embedded in a range } \\
\text { of common contexts where the } \\
\text { mathematical content is fairly explicit or } \\
\text { visual with relatively few distractors. Tasks } \\
\text { tend to require the application of two or } \\
\text { more steps or processes involving } \\
\text { calculation with whole numbers and } \\
\text { common decimals, percentages and } \\
\text { fractions; simple measurement and spatial } \\
\text { representation; estimation; and } \\
\text { interpretation of relatively simple data and } \\
\text { statistics in texts, tables and graphs. }\end{array}$ \\
\hline 3 & $\begin{array}{l}276 \text { to } \\
\text { less } \\
\text { than } \\
326 \\
\text { points }\end{array}$ & $\begin{array}{l}\text { Texts at this level are often dense or } \\
\text { lengthy, and include continuous, non- } \\
\text { continuous, mixed, or multiple pages of } \\
\text { text. Understanding text and rhetorical } \\
\text { structures become more central to } \\
\text { successfully completing tasks, especially } \\
\text { navigating complex digital texts. Tasks } \\
\text { require the respondent to identify, } \\
\text { interpret, or evaluate one or more pieces } \\
\text { of information, and often require varying } \\
\text { levels of inference. Many tasks require the } \\
\text { respondent to construct meaning across } \\
\text { larger chunks of text or perform multi- } \\
\text { step operations in order to identify and } \\
\text { formulate responses. Often tasks also } \\
\text { demand that the respondent disregard } \\
\text { irrelevant or inappropriate content to } \\
\text { answer accurately. Competing } \\
\text { information is often present, but it is not } \\
\text { more prominent than the correct } \\
\text { information. }\end{array}$ & $\begin{array}{l}\text { Tasks at this level require the respondent to } \\
\text { understand mathematical information that } \\
\text { may be less explicit, embedded in contexts } \\
\text { that are not always familiar and } \\
\text { represented in more complex ways. Tasks } \\
\text { require several steps and may involve the } \\
\text { choice of problem-solving strategies and } \\
\text { relevant processes. Tasks tend to require } \\
\text { the application of number sense and spatial } \\
\text { sense; recognising and working with } \\
\text { mathematical relationships, patterns, and } \\
\text { proportions expressed in verbal or } \\
\text { numerical form; and interpretation and } \\
\text { basic analysis of data and statistics in texts, } \\
\text { tables and graphs. }\end{array}$ \\
\hline 4 & $\begin{array}{l}326 \text { to } \\
\text { less } \\
\text { than } \\
376 \\
\text { points }\end{array}$ & $\begin{array}{l}\text { Tasks at this level often require } \\
\text { respondents to perform multiple-step } \\
\text { operations to integrate, interpret, or } \\
\text { synthesise information from complex or } \\
\text { lengthy continuous, non-continuous, } \\
\text { mixed, or multiple type texts. Complex } \\
\text { inferences and application of background } \\
\text { knowledge may be needed to perform the } \\
\text { task successfully. Many tasks require } \\
\text { identifying and understanding one or }\end{array}$ & $\begin{array}{l}\text { Tasks at this level require the respondent to } \\
\text { understand a broad range of mathematical } \\
\text { information that may be complex, abstract } \\
\text { or embedded in unfamiliar contexts. These } \\
\text { tasks involve undertaking multiple steps } \\
\text { and choosing relevant problem-solving } \\
\text { strategies and processes. Tasks tend to } \\
\text { require analysis and more complex } \\
\text { reasoning about quantities and data; } \\
\text { statistics and chance; spatial relationships; }\end{array}$ \\
\hline
\end{tabular}




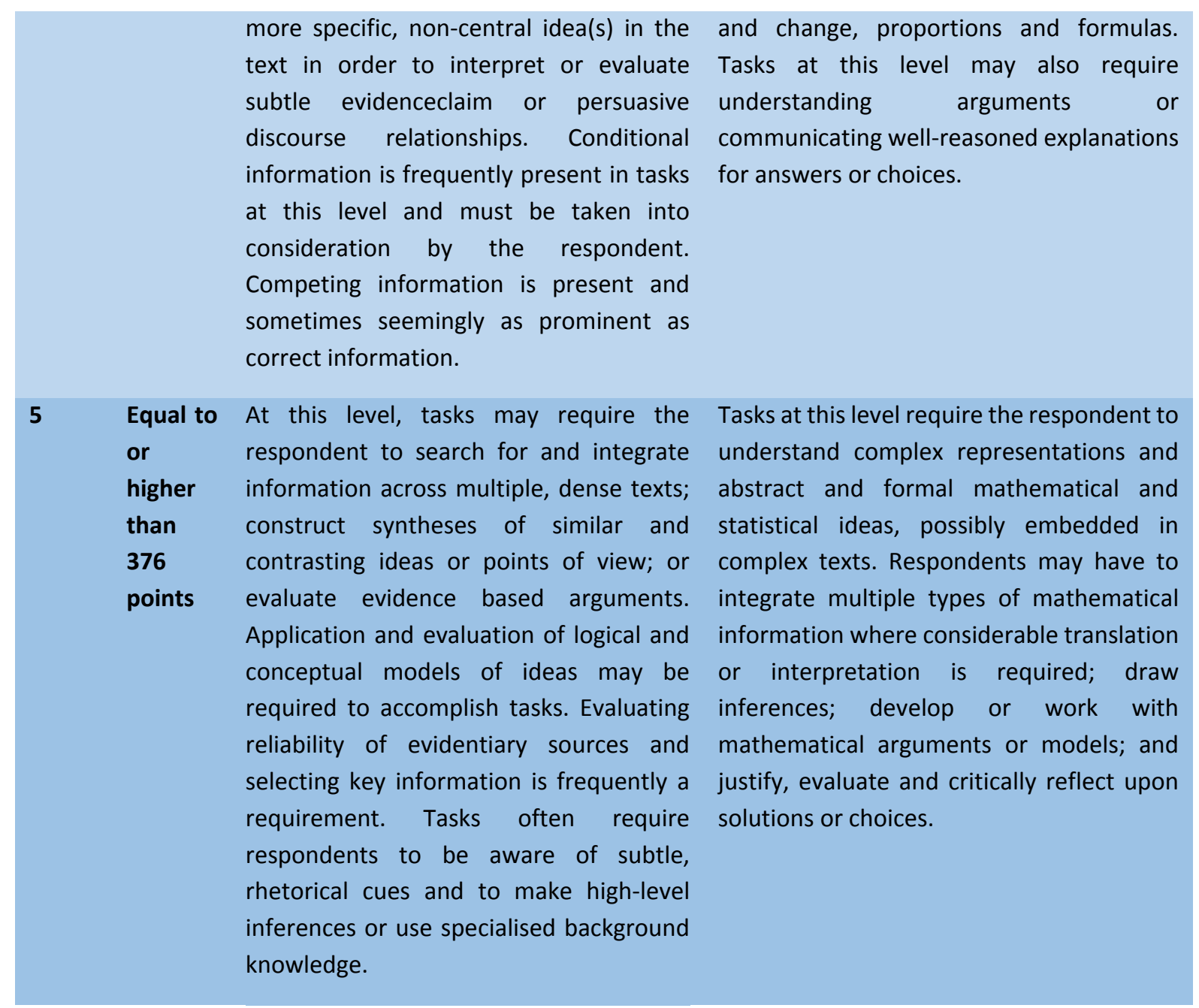

Note: Adapted from The Survey of Adult Skills: Reader's Companion (pp. 69-70), by OECD, 2013. OECD Publishing. The model occupations section is self created, based on data from International Labour Office (2012) and O*NET (2019). 


\section{Appendix 3: Example of the supplementary material}

\section{Physicists and Astronomers}

\section{Definition and Tasks:}

Physicists and astronomers conduct research and improve or develop concepts, theories and operational methods concerning matter, space, time, energy, forces and fields and the interrelationship between these physical phenomena. They apply scientific knowledge relating to physics and astronomy in industrial, medical, military or other fields.

Tasks include:

a) conducting research and improving or developing concepts, theories, instrumentation, software and operational methods related to physics and astronomy;

b) conducting experiments, tests and analyses on the structure and properties of matter in fields such as mechanics, thermodynamics, electronics, communications, power generation and distribution, aerodynamics, optics and lasers, remote sensing, medicine, sonics, magnetism and nuclear physics;

c) evaluating results of investigations and experiments and expressing conclusions, mainly using mathematical techniques and models;

d) applying principles, techniques and processes to develop or improve industrial, medical, military and other practical applications of the principles and techniques of physics or astronomy;

e) ensuring the safe and effective delivery of radiation (ionizing and non-ionizin) to patients to achieve a diagnostic or therapeutic result as prescribed by a medical practitioner;

f) ensuring the accurate measurement and characterization of physical quantities used in medical applications;

g) testing, commissioning and evaluating equipment used in applications such as imaging, medical treatment and dosimetry;

h) advising and consulting with medical practitioners and other health care professionals in optimizing the balance between the beneficial and deleterious effects of radiation;

i) observing, analysing and interpreting celestial phenomena and developing methods, numerical models and techniques to extend knowledge of fields such as navigation, satellite communication, space exploration, celestial bodies and cosmic radiation;

j) developing, implementing and maintaining standards and protocols for the measurement of physical phenomena and for the use of nuclear technology in industrial and medical applications;

k) preparing scientific papers and reports.

Examples of the occupations classified here: Astronomer, Medical physicist, Nuclear physicist, Physicist.

Some related occupations classified elsewhere: Radiation oncologist - 2212, Radiologist - 2212, Specialist physician (nuclear medicine) - 2212, Radiographer - 3211. 
It should be noted that, while they are appropriately classified in this unit group with other physicists, medical physicists are considered to be an integral part of the health workforce alongside those occupations classified in Sub-major Group 22: Health Professionals and others classified in a number of other unit groups in Major Group 2: Professionals

\section{Required Education and Experience:}

Education: Most of these occupations require graduate school. For example, they may require a master's degree, and some require a Ph.D.

Experience: Extensive skill, knowledge, and experience are needed for these occupations. Many require more than five years of experience.

Job Employees may need some on-the-job training, but most of these occupations

Training: assume that the person will already have the required skills, knowledge, work-related experience, and/or training. 


\section{Appendix 4: Names and affiliations of the participating experts}

\begin{tabular}{|c|c|}
\hline Name & Affiliation \\
\hline Margaret Birch & $\begin{array}{l}\text { Senior Research Administrator at the Warwick Institute for Employment } \\
\text { Research (University of Warwick) }\end{array}$ \\
\hline Peter Elias & $\begin{array}{l}\text { Professor at the Warwick Institute for Employment Research (University of } \\
\text { Warwick) }\end{array}$ \\
\hline $\begin{array}{l}\text { Christy Marie } \\
\text { Gregory }\end{array}$ & Principal Owner at Job Networking Solutions, LLC \\
\hline David Hunter & Senior Consultant and Managing Director at StatClass Sàrl \\
\hline Phil Lewis & Technical Officer at National Center for O*NET Development \\
\hline $\begin{array}{l}\text { Jean-François } \\
\text { Rouet }\end{array}$ & $\begin{array}{l}\text { Chair of the PIAAC Literacy Expert Group } \\
\text { French National Centre for Scientific Research (University of Poitiers) }\end{array}$ \\
\hline Folker Schrödel & Editor at BW Verlag Bildung und Wissen \\
\hline David Tout & $\begin{array}{l}\text { Chair of the PIAAC Numeracy Expert Group } \\
\text { Australian Council for Educational Research }\end{array}$ \\
\hline
\end{tabular}




\title{
Required literacy and numeracy skill levels for occupations in OECD countries
}

\section{Application of the Job Analysis Method to PIAAC}

\author{
Sandra Pérez Rodríguez \\ Tim Huijts \\ Rolf van der Velden \\ Babs Jacobs
}

ROA-TR-2020/8

September 2020

Research Centre for Education and the Labour Market Maastricht University

P.O. Box 616, 6200 MD Maastricht, The Netherlands

$\mathrm{T}+31433883647 \mathrm{~F}+31433884914$

secretary-roa-sbe@maastrichtuniversity.nl

www.roa.nl

ISSN: $2666-884 X$ 